\title{
Polypore fungi as a flagship group to indicate changes in biodiversity - a test case from Estonia
}

\author{
Kadri Runnel ${ }^{1^{*}} \mathbb{D}$, Otto Miettinen ${ }^{2}$ and Asko Lõhmus ${ }^{1}$
}

\begin{abstract}
Polyporous fungi, a morphologically delineated group of Agaricomycetes (Basidiomycota), are considered well studied in Europe and used as model group in ecological studies and for conservation. Such broad interest, including widespread sampling and DNA based taxonomic revisions, is rapidly transforming our basic understanding of polypore diversity and natural history. We integrated over 40,000 historical and modern records of polypores in Estonia (hemiboreal Europe), revealing 227 species, and including Polyporus submelanopus and $P$. ulleungus as novelties for Europe. Taxonomic and conservation problems were distinguished for 13 unresolved subgroups. The estimated species pool exceeds 260 species in Estonia, including at least 20 likely undescribed species (here documented as distinct DNA lineages related to accepted species in, e.g., Ceriporia, Coltricia, Physisporinus, Sidera and Sistotrema). Four broad ecological patterns are described: (1) polypore assemblage organization in natural forests follows major soil and tree-composition gradients; (2) landscape-scale polypore diversity homogenizes due to draining of peatland forests and reduction of nemoral broad-leaved trees (wooded meadows and parks buffer the latter); (3) species having parasitic or brown-rot life-strategies are more substratespecific; and (4) assemblage differences among woody substrates reveal habitat management priorities. Our update reveals extensive overlap of polypore biota throughout North Europe. We estimate that in Estonia, the biota experienced ca. 3-5\% species turnover during the twentieth century, but exotic species remain rare and have not attained key functions in natural ecosystems. We encourage new regional syntheses on long studied fungal groups to obtain landscape-scale understanding of species pools, and for elaborating fungal indicators for biodiversity assessments.
\end{abstract}

Keywords: Assemblage composition, Cryptic species, Functional groups, Species pool, Substrate ecology, Woodinhabiting fungi

\section{INTRODUCTION}

The fact that global biodiversity trends are assessed almost without a fungal perspective (e.g., Butchart et al. 2010, IPBES 2018) calls into question how we should integrate scattered mycological knowledge. Historically, regional checklists of fungal biotas have served such aims (e.g., Senn-Irlet et al. 2007), but the rapid advancement

\footnotetext{
* Correspondence: kadri.runnel@ut.ee

${ }^{1}$ Department of Zoology, Institute of Ecology and Earth Sciences, University of Tartu, Vanemuise 46, 51005 Tartu, Estonia

Full list of author information is available at the end of the article
}

of molecular methods and mass data accumulating from ecological assemblage studies challenge such integration (e.g., Peay 2014, Thomson et al. 2018). Thus, molecular biodiversity research is searching its way out of slow nomenclatural procedures (Hibbett 2016); for example, through a concept of species hypothesis based on DNA barcoding (Kõljalg et al. 2013). This causes accumulation of 'dark taxa' that lack names or even physical specimens, which cannot currently be used in conventional taxonomy or conservation (Ryberg \& Nilsson 2018). For ecological research programs and environmental

(c) The Author(s). 2021 Open Access This article is licensed under a Creative Commons Attribution 4.0 International License, which permits use, sharing, adaptation, distribution and reproduction in any medium or format, as long as you give appropriate credit to the original author(s) and the source, provide a link to the Creative Commons licence, and indicate if changes were made. The images or other third party material in this article are included in the article's Creative Commons licence, unless indicated otherwise in a credit line to the material. If material is not included in the article's Creative Commons licence and your intended use is not permitted by statutory regulation or exceeds the permitted use, you will need to obtain permission directly from the copyright holder. To view a copy of this licence, visit http://creativecommons.org/licenses/by/4.0/. 
management, taxonomic and nomenclatural revisions can be too dynamic or impractical, such as when new species are described without morphologically distinct characters (e.g., Korhonen et al. 2018). As a consequence, ecological studies remain taxonomically heterogeneous, often simplified or of unknown quality (Bortolus 2008, Vink et al. 2012), and may omit taxa of critical conservation importance (e.g., rare undescribed species). Taxonomic descriptions, in turn, include only very basic ecological data and seldom report populationand ecosystem-scale context (Durkin et al. 2020). Conservationists have responded with calls to transform taxonomically accepted species lists into special conservation lists to resolve the administrative problem of taxonomic instability (Mace 2004).

With a broader aim to reintegrate disciplines for monitoring fungal diversity, this study provides a new regional synthesis of polyporous fungi (Agaricomycetes: Basidiomycota; hereafter: polypores) - a conspicuous and well-studied fungal morphogroup. Polypores are distinguished based on poroid hymenophore and mostly lignicolous lifestyle; they inhabit forests on all continents. In recent overviews for Europe and NorthAmerica, the number of polypore species was assessed at 400 and 492, accordingly (Zhou et al. 2016, Ryvarden \& Melo 2017). Historically, all polypores were included into a common family, Polyporaceae, within the order Aphyllophorales (Fries 1874). This higher classification based on basidiome morphology was refined by several mycologists in the twentieth century, most notably by Singer (1944), Donk (1948, 1964, 1971), and Jülich (1981), but has been largely rejected since the introduction of molecular systematics. The name Polyporales now only refers to one of at least 12 orders within Agaricomycetes that include fungi with polyporoid basidiomes (Hibbett et al. 2014). Polyporous 'morphogenera' are increasingly replaced by molecularly supported clades that may be closely related to, or even comprise, nonpolyporoid fungi (e.g., Miettinen et al. 2012; Runnel et al. 2019). Molecular data have also revealed extensive undescribed species diversity, including morphologically indistinguishable (cryptic) taxa (e.g., Korhonen et al. 2018). Despite these changes in taxonomy and systematics, polypores continue to be treated as a morphogroup in local and regional studies (e.g., Dai 2012, Zhou et al. 2016, Ryvarden \& Melo 2017), and in ecological and conservation research. The reasons for that include acceptance by conservationists and educational values.

Functional significance is a major reason why polypores remain a distinct object of research, especially in the fields of forest ecology and conservation. These fungi constitute important decayers, specifically of the huge woody biomass and its lignin component in forests (Floudas et al. 2012). Their mycelia and basidiomes attached to wood provide forage or microhabitat for diverse assemblages of saproxylic invertebrates (e.g., Birkemoe et al. 2018). A subset of polypore species parasitize live trees, some bearing significant economic and social costs for production forestry and arboriculture through root-, butt- and heart-rots (Schwarze et al. 2013). Ecologically, however, heart-rots are key processes in the formation of tree cavities supporting forest fauna (Remm \& Lõhmus 2011), while root- and butt-rots promote tree uprooting and trunk breakage (Honkaniemi et al. 2017) that create diverse microhabitats in forests. Several polypore genera include mostly mycorrhizal species, some of which form basidiomes on dead wood (e.g., among Sistrotrema; Nilsson et al. 2006, Di Marino et al. 2008). Polypores are best studied in North and Central Europe where intensive forest management has been threatening their diversity - this has facilitated their use for assessing forest conservation values and planning the management (Junninen \& Komonen 2011, Halme et al. 2017). Linked with these practical issues has been theoretical interest in polypores as model taxa for metapopulation and assemblage models applicable to dynamic habitat patches (e.g., Ovaskainen et al. 2010; Ramiadantsoa et al. 2018).

To explore the perspectives of this flagship group for fungal diversity assessment, we synthesize diverse information from Estonia - a North European country in the hemiboreal (boreo-nemoral) vegetation zone. The first reliable data on Estonian polypore biota were published in the overview by Dietrich $(1856,1859)$. Local surveys, with an emphasis on (forest) pathology, were initiated by Elmar Lepik (Leppik) in the late 1920s; he also rechecked and summarized the previously collected material from Estonia (e.g., Lepik 1931, 1940). The forest pathology research direction soon focussed on a few economically significant taxa: Heterobasidion species causing butt-rots in conifers (e.g., Karu 1953, Hanso \& Hanso 1999) and Phellinus tremulae causing heart-rot in European aspen (Populus tremula) (reviewed by Tamm 2000). A wider research perspective on polypores, accompanied with taxonomic work, was developed in the second half of the twentieth century by Erast Parmasto (Parmasto 2012). Parmasto (2004) published a monograph that quantitatively summarized all the distribution data on the 211 species then known, their main habitat types and host trees. In the 1990s, Parmasto focused on species sensitive to loss of old-growth forests (Parmasto \& Parmasto 1997, Parmasto 2001); this research line has been recently re-assessed based on ecological sampling (e.g., Runnel \& Lõhmus 2017). Overall, there has been a large increase in polypore data since 2004 from ecological studies, including the development and testing of the survey methods (Runnel et al. 2015, Lõhmus et al. 2018a). Also species' distribution mapping has 
continued, notably through monitoring protected species and in protected areas. However, this new knowledge has remained scattered among projects, and the historical data have not been taxonomically updated.

Our synthesis of the diversity and ecology of Estonian polypores serves three broad aims: (1) We characterize the country-scale species pool in a regional perspective, including taxonomic uncertainties. We do not omit unresolved material; instead, we combine and present molecular phylogenies and habitat data of 'difficult' specimens to address the primary aim of describing (full) biodiversity. (2) By critically comparing the updated checklist with Parmasto (2004), we distinguish actual long-term changes in the biota from the advancement of knowledge. And (3) we pool all ecological data to quantitatively analyse compositional similarity of Estonian polypore assemblages and niche characteristics of species. At the ecosystem scale, we assess correspondence between polypore assemblages and the habitat type, specifically in relation to soil conditions, tree composition and stand age. This addresses the 'Cajanderian' approach to boreal forest typology, which is based on stable site types rather than temporary conditions (e.g., Frey 1973, Lahti \& Väisänen 1987). The practical importance of our ecological analyses is to provide a basis for land-cover or substrate-type proxies for conserving polypore diversity (termed 'coarse-filter' and 'mesofilter' approaches in conservation biology, respectively; Hunter 2005, Cushman et al. 2008).

\section{MATERIAL AND METHODS}

\section{Study region and ecosystems}

Estonia has a total land area $45,339 \mathrm{~km}^{2}$, of which ca. $10 \%$ encompasses its western archipelago in the Baltic Sea. The country is situated in the European hemiboreal vegetation zone (Ahti et al. 1968); the natural land cover in the absence of human impact would comprise ca. $85 \%$ forest, $8 \%$ open wetlands and $5 \%$ lakes (Laasimer 1965). The mean air temperature is $17^{\circ} \mathrm{C}$ in July and $-4{ }^{\circ} \mathrm{C}$ in January and the average precipitation is $600-700 \mathrm{~mm}$ $\mathrm{yr}^{-1}$. The topography is mostly of glacial origin. Lowlands (post-glacial flooded plains reaching less than $50 \mathrm{~m}$ above current sea level) cover nearly half of the territory, and are the dominant land-forms in West-Estonia. The bases of two erosional and three accumulative uplands are $75-100 \mathrm{~m}$ above sea level; four of these uplands are in southern Estonia.

Western and eastern Estonia are separated by a borderline of post-glacial landscape history, climate conditions, and land-use patterns (Ahti et al. 1968; Raukas et al. 2004). The last ice sheet retreated ca. five thousand years earlier in the east (Raukas et al. 2004), which now has a more continental climate with isotherm differences up to $4-5{ }^{\circ} \mathrm{C}$ compared with western Estonia (Jõgi \&
Tarand 1995). This border can be also recognised in the distribution of biodiversity, such as plants (Laasimer 1965) and epiphytic lichens (Jüriado et al. 2003).

Forests, the main ecosystem hosting polypores, currently cover $51 \%$ of Estonia but, after a long history of land use, only $2 \%$ of this is old natural stands (Raudsaar et al. 2018). Forest conversion to agriculture reached its maximum by the 1930s when ca. one-third of the country had woodland cover (Meikar \& Uri 2000). Subsequent afforestation mostly took place due to the abandonment of small agricultural fields and wetland drainage for forestry. Timber harvest intensities were relatively low in the second half of the twentieth century, but rapidly increased after the country regained independence: from 2 to 3 million $\mathrm{m}^{3}$ in 1991-1993 to 10 12 million $\mathrm{m}^{3}$ in $2000-2001$ where the volume stabilized, after a temporary decline, since 2011. In the same period, strictly protected forest reserves were expanded from ca. 3 to $13 \%$ of forest land (Lõhmus et al. 2004, Raudsaar et al. 2018). The forest management has been based on native tree species and, to a significant extent, on natural regeneration ('semi-natural forestry'), but following the even-aged (clear-cutting based) silvicultural system and including planting (mostly conifers), thinning, and artificial drainage. Such a mixture of approaches maintained commercial forests in a relatively favourable state for wood-inhabiting species (Lõhmus et al. 2016, Runnel \& Lõhmus 2017). However, recent developments to lower rotation age, increase cut-block size, subsidized planting, and (in private forests) ditching threaten forest biodiversity in a longer perspective (e.g., Lõhmus et al. 2018b).

Based upon edaphic and hydrological factors, nine natural and two anthropogenic forest site type groups (drained peatlands; reclaimed areas), comprising at least 27 forest site types, are distinguished for the practical planning and monitoring of Estonian forests (Lõhmus 1984, Raudsaar et al. 2018; Additional file 1). Common natural site type groups are meso-eutrophic (27\%; usually Norway spruce Picea abies mixtures with deciduous trees), dry boreal (23\% of forest land; most dominated by Scots pine, Pinus sylvestris), eutrophic paludifying (16\%; mostly birch Betula spp., often in mixtures with $P$. sylvestris), and eutrophic boreo-nemoral forests (10\%; typically Betula spp., Populus tremula, and grey alder Alnus incana). The dominant anthropogenic forests are drained peatland forests (14\%; mostly Betula spp. and P. sylvestris). All the main forest trees are native; $31 \%$ of forest area is dominated by P. sylvestris, $30 \%$ by Betula spp., 19\% by $P$. abies, $9 \%$ by Alnus incana and $6 \%$ by P. tremula (Raudsaar et al. 2018). Stands of exotic trees comprise $0.1 \%$ of forest land. Over $25 \%$ of the forest land has been drained and over 300,000 ha planted, 
but there are few intensive plantations and stands usually consist of more than one (most often three) tree species.

The main secondary habitats for polypores are seminatural and urban areas with sparse tree cover. Of these, most traditional wooded meadows were lost during the twentieth century due to the re-organization of agriculture; only < 10,000 ha remain (Sammul et al. 2008). Compared with Western Europe, the Estonian agricultural landscapes still retain significant areas with natural components such as scattered tree rows and single trees (e.g., Kikas et al. 2018). Biodiversity hotspots in the countryside include rural parks that may have dead wood amounts comparable with those in production forests (e.g., Lõhmus \& Liira 2013), and riparian zones that contain specific habitats (such as large Salix trees) rarely found in forests. Finally, ca. 2\% of Estonian land cover comprises human settlements, often with a significant proportion of green space and trees. A distinct polypore habitat feature of the green space is a diverse mixture of exotic tree species, planted as ornamental species or sometimes as tree collections. Tallinn alone (excluding its botanical garden) hosts 449 exotic species in addition to the 31 native species of trees (Sander et al. 2003).

\section{Estonian polypore data}

The Estonian polypore data used includes $c a 40,500$ basidiome records (Table 1). A 'record' refers to collected specimens or archived observations, usually at the level of one distinct substrate unit (e.g., a single fallen trunk). About $10 \%$ of records - such as some historical species lists and ecological studies (e.g., Lõhmus 2011) refer to occurrences at the scale of a forest stand. The specimens we collected are deposited in the fungaria of Tartu University (TU) and the Estonian University of
Life Sciences (TAAM); all these records, together with their molecular DNA data and occasional photographs, are archived in the PlutoF database (Abarenkov et al. 2010). At the time of compiling of this study, the molecular data (mostly ITS sequences; in a minority of cases additionally LSU sequences) were available for 3\% of all records (Table 1).

The material comprised three methodologically distinct parts.

(I) One-third of the material were all records until 2004, which were originally summarized by Parmasto (2004). These are mostly specimens collected during casual surveys by Parmasto and his colleagues in the period 1950-2004, and a critical revision of all older collections. The material has been sampled throughout the country, although some regions (such as eastern and south-western Estonia) have been more intensively covered (Fig. 1A). Parmasto (2004) admits paying more attention to Phellinus (sensu lato) and old-forest fungi; a re-analysis of the whole dataset by Lõhmus (2009) suggested a more general bias (compared with frequencies in nature) toward easily recognizable species with perennial basidiomes. A preference to visit certain biodiversity 'hotspots' (such as protected areas, some maritime islands and certain city parks) is also obvious in the location data. For the current study, most original specimens of poorly identifiable rare species (see Lõhmus 2009 and under "Difficult species" below) were morphologically re-checked and, by necessity, sequenced (Table 1).

(II) Fifty-seven percent of all records were obtained from systematic surveys of polypore assemblages by

Table 1 Main sources of the Estonian polypore data

\begin{tabular}{|c|c|c|c|}
\hline Data source or sampling design & $\begin{array}{l}\text { No. of records } \\
\text { (sequences) }^{a}\end{array}$ & Studied ecosystems & Publications \\
\hline I. Historical data until 2004 & $13,249(48)$ & All & Parmasto 2004 \\
\hline $\begin{array}{l}\text { Ila. Systematic sampling in a } 4-\mathrm{km}^{2} \text { forest } \\
\text { landscape in E Estonia, 2008-2009 }\end{array}$ & $3560(3)$ & $\begin{array}{l}\text { All forest land; mostly eutrophic and } \\
\text { meso-eutrophic mixed sites }\end{array}$ & Lõhmus 2011 \\
\hline $\begin{array}{l}\text { Ilb. Standard surveys in } 30 \text { 2-ha plots and } \\
\text { their surroundings in SW Estonia, } 2013\end{array}$ & $2393(122)$ & $\begin{array}{l}\text { Pinus sylvestris dominated drained } \\
\text { peatland forests }\end{array}$ & $\begin{array}{l}\text { Runnel et al. } 2015 \\
\text { https://doi.org/10.15156/BIO/786358 }\end{array}$ \\
\hline $\begin{array}{l}\text { Ilc. Standard surveys in } 144 \text { 2-ha plots, } \\
\text { 2005-2016 }\end{array}$ & $17,012(334)$ & $\begin{array}{l}\text { Forests and clear-cuts of various types, } \\
\text { except of bog and drained wetland } \\
\text { types }\end{array}$ & $\begin{array}{l}\text { Runnel \& Lõhmus } 2017 \\
\text { https://doi.org/10.15156/BIO/786363 } \\
\text { https://doi.org/10.15156/BIO/786357 }\end{array}$ \\
\hline $\begin{array}{l}\text { Ild. Fallen retention trees in } 48 \text { clear-cuts in } \\
\text { mainland, 2010-2011 }\end{array}$ & $259(19)$ & Sites on mineral soils & Runnel et al. 2013 \\
\hline IIla. Casual collections after 2004 & $3020(631)$ & All & PlutoF database \\
\hline $\begin{array}{l}\text { Illb. Surveys of } 27 \text { species in protected } \\
\text { areas, 2015-2016 }\end{array}$ & $922(89)$ & All & PlutoF database (partly) \\
\hline Total & $40,415(1246)$ & & \\
\hline
\end{tabular}

${ }^{a}$ no. of sequences deposited in the PlutoF database (Abarenkov et al. 2010) 


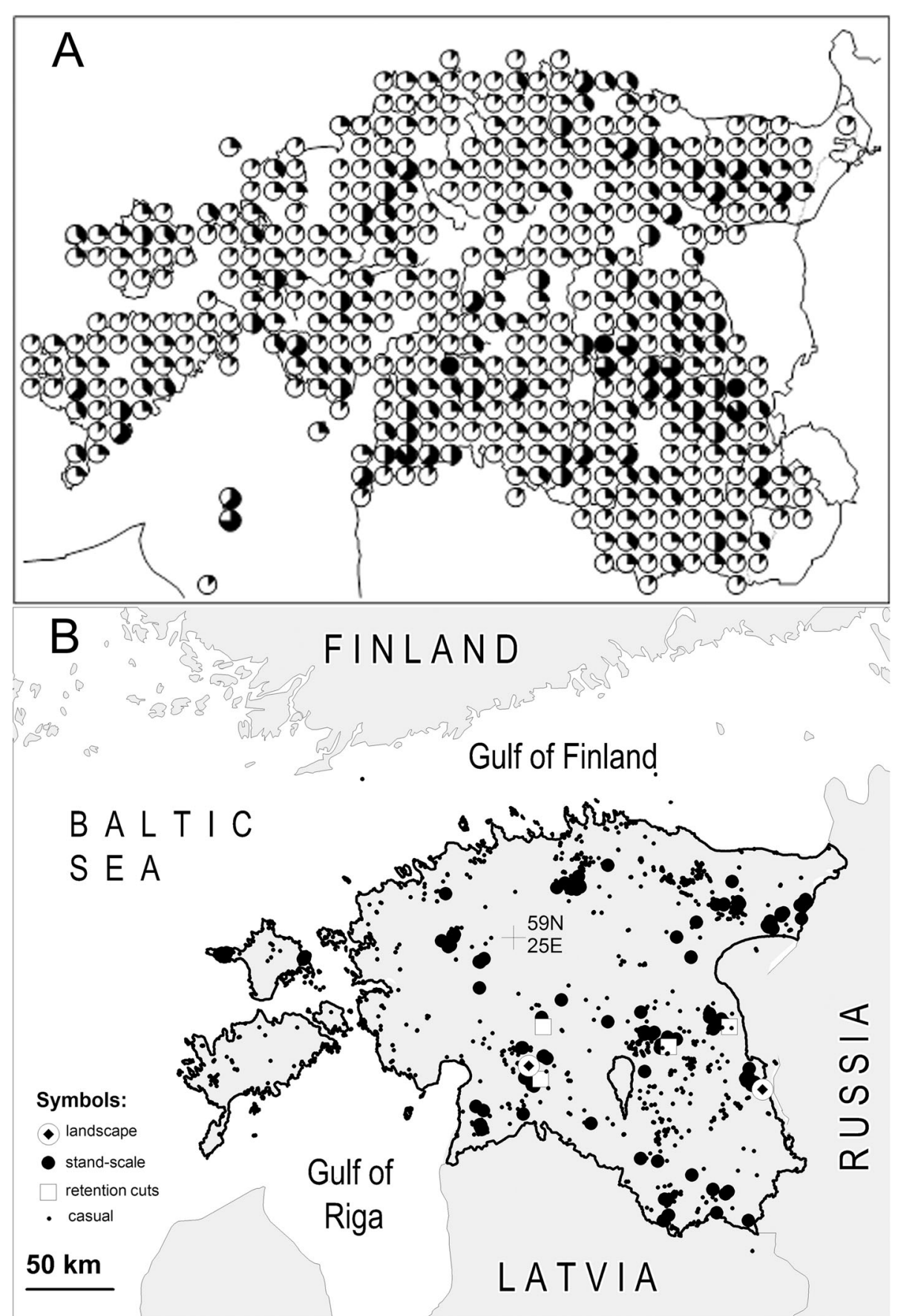

Fig. 1 Distribution of the Estonian polypore datasets included in this study. a Data until 2004: relative no. of species of the total species pool on the $10 \times 10 \mathrm{~km}$ UTM-grid as reported by Parmasto (2004). b Systematic surveys and casual records in 2005-2018. 'Landscape' surveys refer to intensive sampling of the Soomaa area in the west (Runnel et al. 2015 and unpubl.) and Aravu area in the east (Lõhmus 2011). 'Stand-scale' surveys are standard-effort surveys in 2-ha plots (Lõhmus et al. 2018a). 'Retention-cut' sampling was from selected trunks (Runnel et al. 2013). Casual records are all other records and observations extracted from PlutoF database, 8 November 2018. Graph (A) reproduced with the permission of the Estonian University of Life Sciences, Tartu

K.R and A.L in 2005-16. These surveys have been planned and (mostly) published to address questions of forest ecology and conservation (Table 1). Accordingly, this material represents most
Estonian forest ecosystems, although it is geographically biased toward mainland Estonia, especially southern, eastern, and north-eastern parts of the country (Fig. 1B). The surveys were 
performed in the top basidiome production season (September-October), with efforts to record all species either at the habitat patch or substrate scale (to analyse also species absences) along with detailed descriptions of the habitats and substrates. The substrate descriptions have routinely included tree species, condition, diameter, and decay stage (five classes, I-V, according to Renvall 1995). About 15\% of the field observations are supported by collections, focusing on basidiomes that could not be reliably identified in the field, represented poorly studied taxa, or atypical substrates (Runnel et al. 2014, Lõhmus et al. 2018a). The collected basidiomes have all been inspected microscopically and ca. $20 \%$ of the specimens have been sequenced (Table 1).

Three field protocols were followed in the systematic surveys. The main set of surveys (Table 1: IIbIIc; $48 \%$ of all records) followed a fixed-area-fixed-effort survey protocol, as presented and analysed for bias by Lõhmus et al. (2018a). Each survey was carried out during $4 \mathrm{~h}$ in a precisely delineated 2-ha plot by a single observer (the plots listed in Additional file 2). For each species in each plot, substrates of the first ten records were described in detail. Up to 150 such records per plot could be obtained within the $4 \mathrm{~h}$. A less thorough method was used in an East Estonian forest landscape study (Table 1: IIa), where all forest stands in a $4-\mathrm{km}^{2}$ area were sampled by adjusting survey time with stand area (range $0.1-7 \mathrm{ha}$; see Lõhmus 2011 for details). For most species, one substrate type in one stand comprised one record, but rare and threatened species were recorded at the scale of individual substrate items. Finally, a small study on retention trees in four Estonian regions recorded all species at the scale of individual tree trunks (Runnel et al. 2013; Table 1: IId).

III Post-2004 casual records comprise 10\% of all records, from two sources (Table 1). The majority are specimen and observation data as extracted on 8 November 2018 from the PlutoF database

(Abarenkov et al. 2010). These data originate from casual surveys similar to Parmasto's (2004) material from professional and, increasingly, amateur mycologists all over Estonia (Fig. 1b). All the observations obtained from the database were quality-scanned, and doubtful identifications were discarded. We additionally included 922 observations of 27 easily identifiable protected, rare or old-forest indicator species (full list is available upon request) during publicly funded fungal surveys by Indrek Sell in two protected areas in mainland Estonia: the Soomaa National Park in 2015 and the Muraka Nature Reserve in 2016.

\section{Data processing}

Updating species list and documenting taxonomic uncertainties For ecological analyses, the set of casual records included in this paper are as of 8 November 2018. However, Table 2 has been updated based on casual collection data (Table 1: IIIa) as of 20 July 2019, with the records of Amylocystis lapponica updated according to Runnel et al. (2020), and Inonotus ulmicola and Spongipellis spumea including the observations by Pau (2018). Phellinus igniarius sensu stricto is defined as all species records from Salix spp.

We use conservative nomenclature for genera whose classification is still in flux, such as Antrodia, Phellinus, Inonotus, and Polyporus.

To update the species list, special attention was paid to specimens that represented taxa with recently updated taxonomy (notably the species concept) and potentially unresolved groups. Such specimens were checked microscopically, and multiple dried basiodiomes sequenced for rDNA ITS (in the case of high variability also D1-D2 domains of the more stable LSU region) for comparisons with references in public databases and our personal database. For obtaining the ITS sequences, we used primers ITS1F (Gardes \& Bruns 1993) or ITS0F-T (Tedersoo et al. 2008) and ITS4 (White et al. 1990); for the D1-D2 domains of the LSU region we used primers CTB6 (Garbelotto et al. 1997) and LR7 (Vilgalys \& Hester 1990) or LBW (Tedersoo et al. 2008). DNA extraction, polymerase chain reaction (PCR), and sequencing of the target loci followed protocols described by Tamm and Põldmaa (2013). ITS and LSU sequences were also produced for 82 species that had no previously sequenced voucher specimens from Estonia.

In eight difficult/unresolved species groups, we explicitly illustrate the variation in their Estonian ITS (in some cases also LSU) sequence material and the accompanying ecological data on substrate and habitat type. The sequences were edited and assembled using Sequencher 5.1 (Gene Codes, Michigan, USA), first aligned automatically using Mafft 7 online version (Katoh et al. 2017) and then edited manually in AliView (Larsson 2014). The Estonian dataset of each taxon group was complemented with the most similar basidiome based sequences ( $>95 \%$ similarity) available at GenBank and UNITE database (Nilsson et al. 2018). In UNITE, a species hypothesis at $1.5 \%$ threshold level was calculated for a voucher specimen of each distinct lineage (Kõljalg et al. 2013). Outgroups were chosen based on the latest molecular taxonomic works on the target taxa, except in Byssoporia, Coltricia cinnamomea, Physisporinus and Sidera that had difficult to align ITS/ 


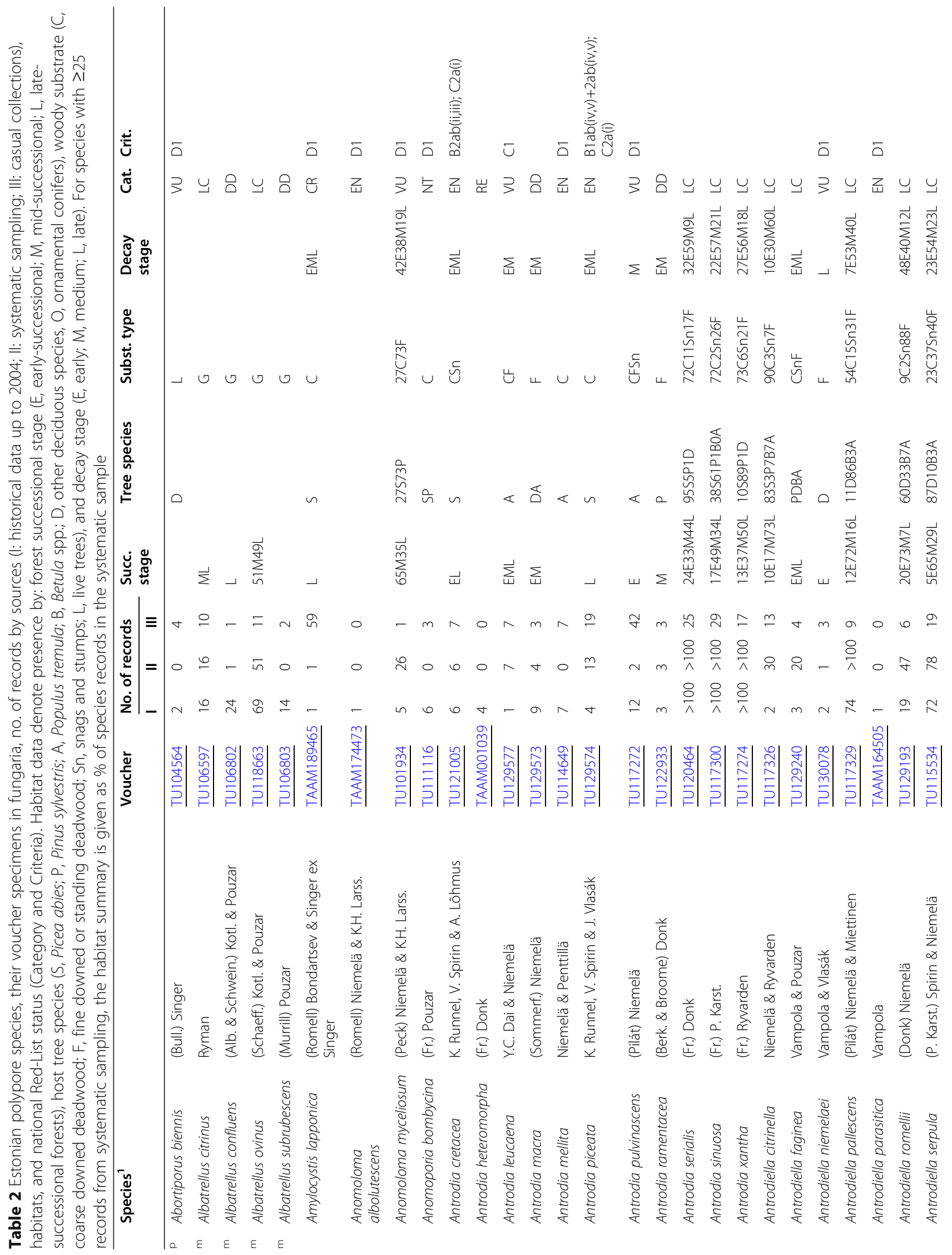




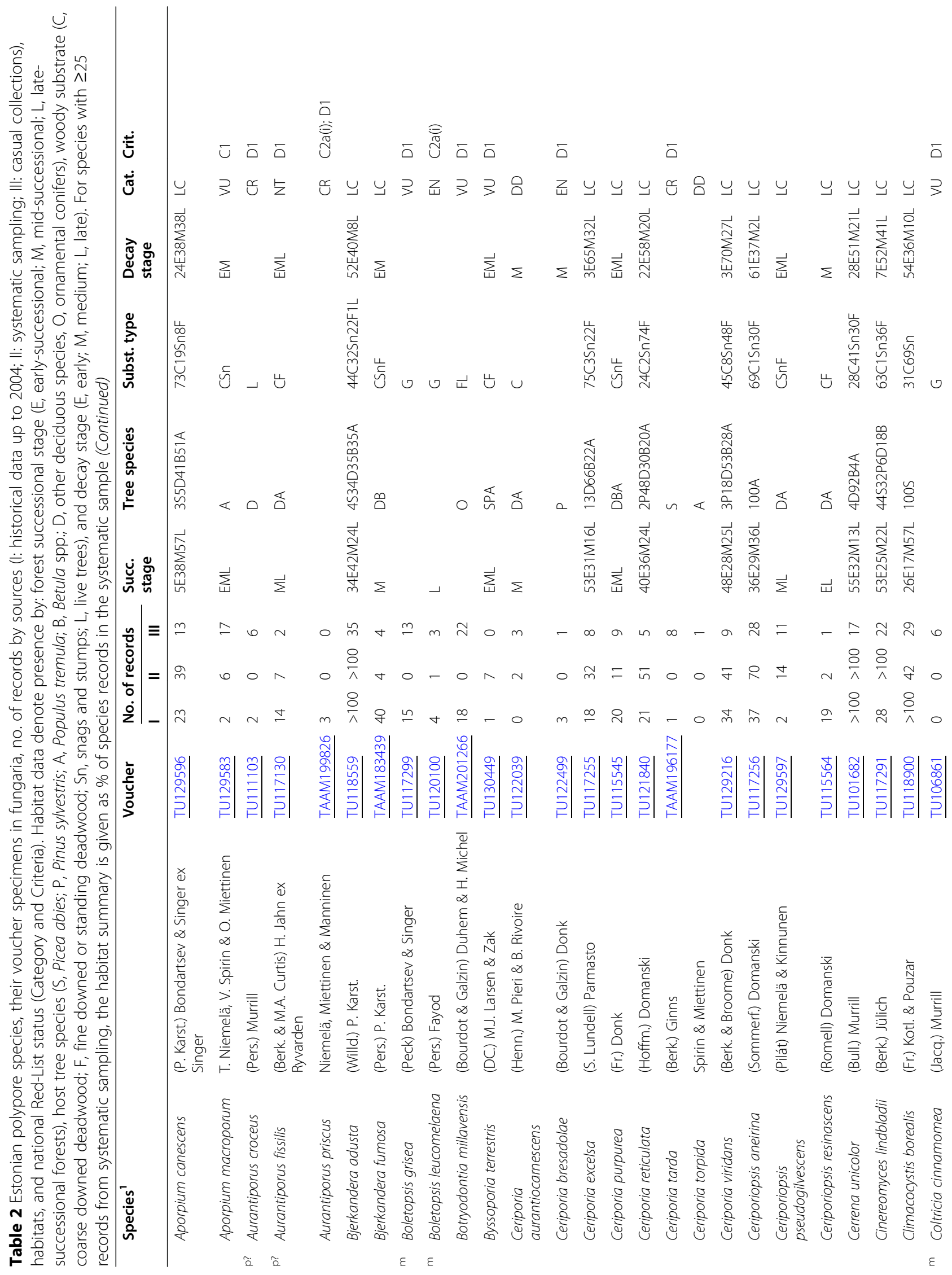




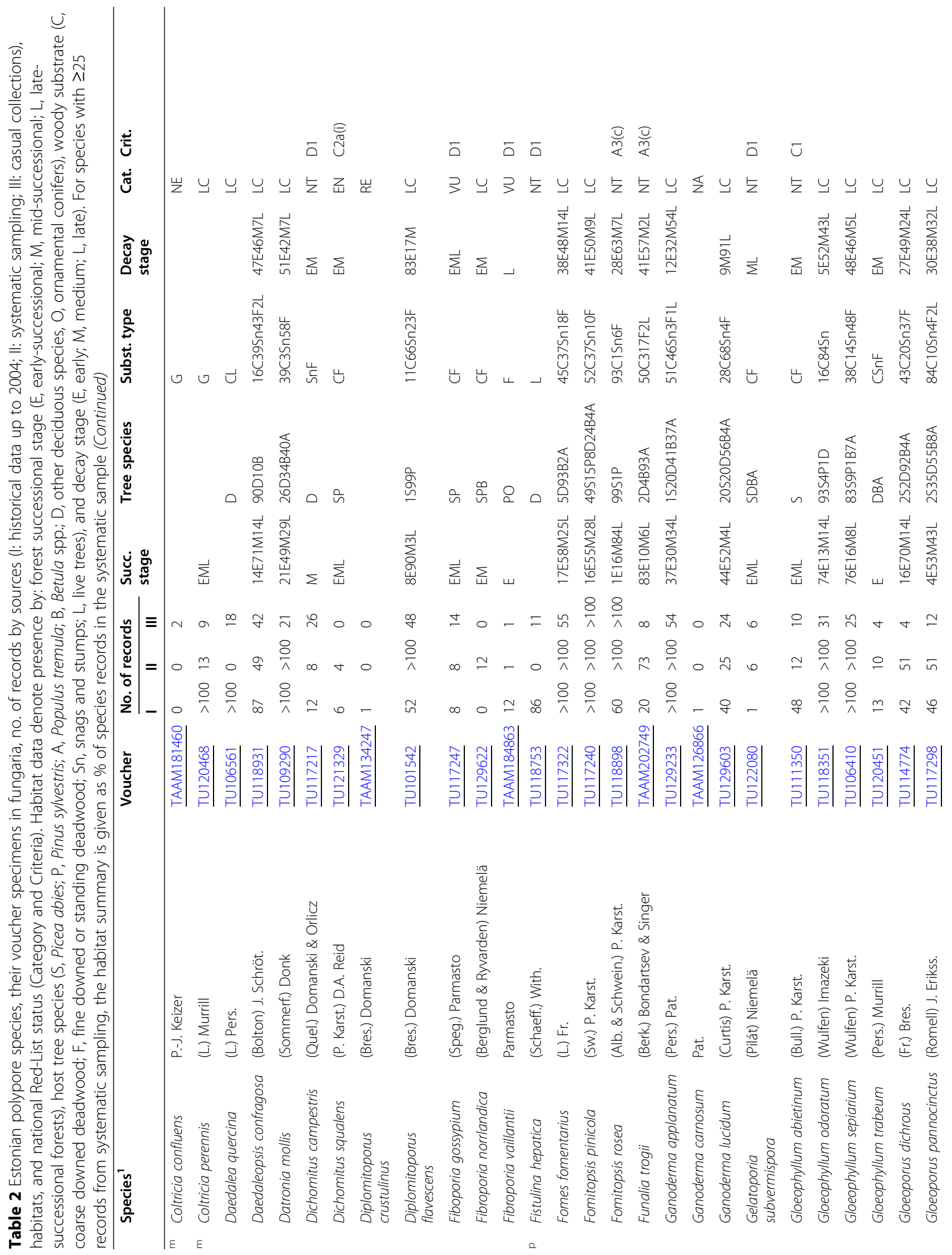




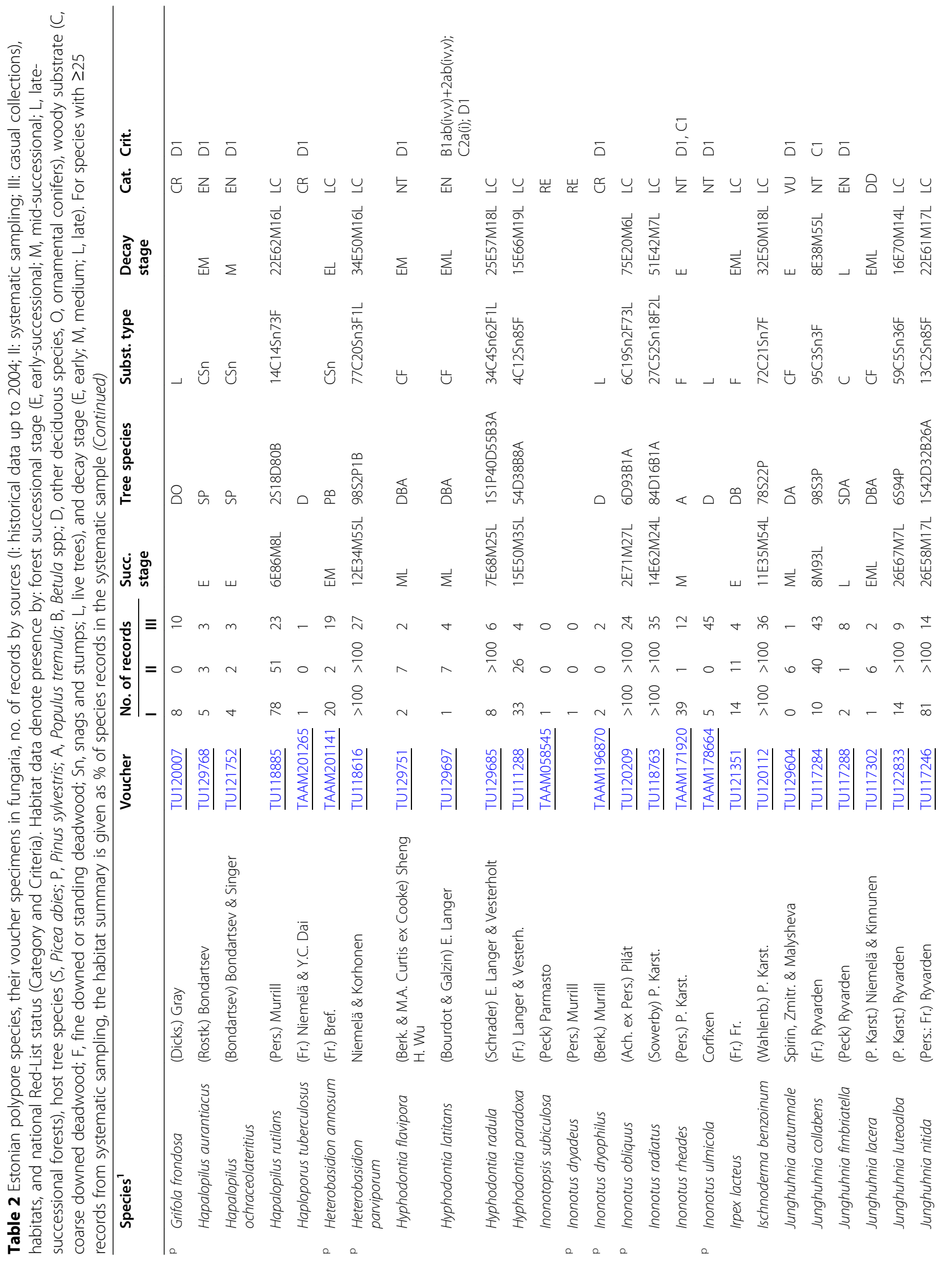




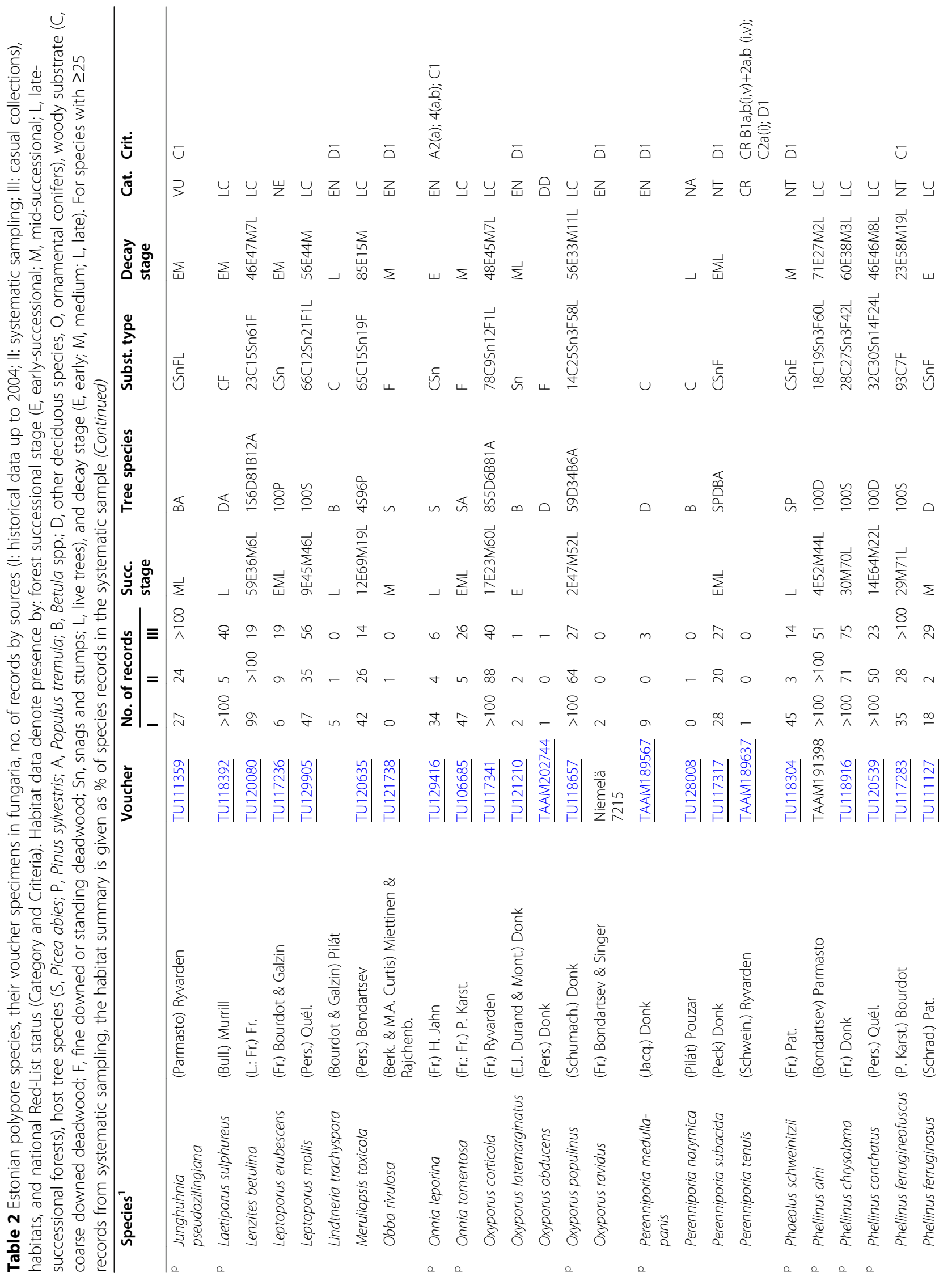




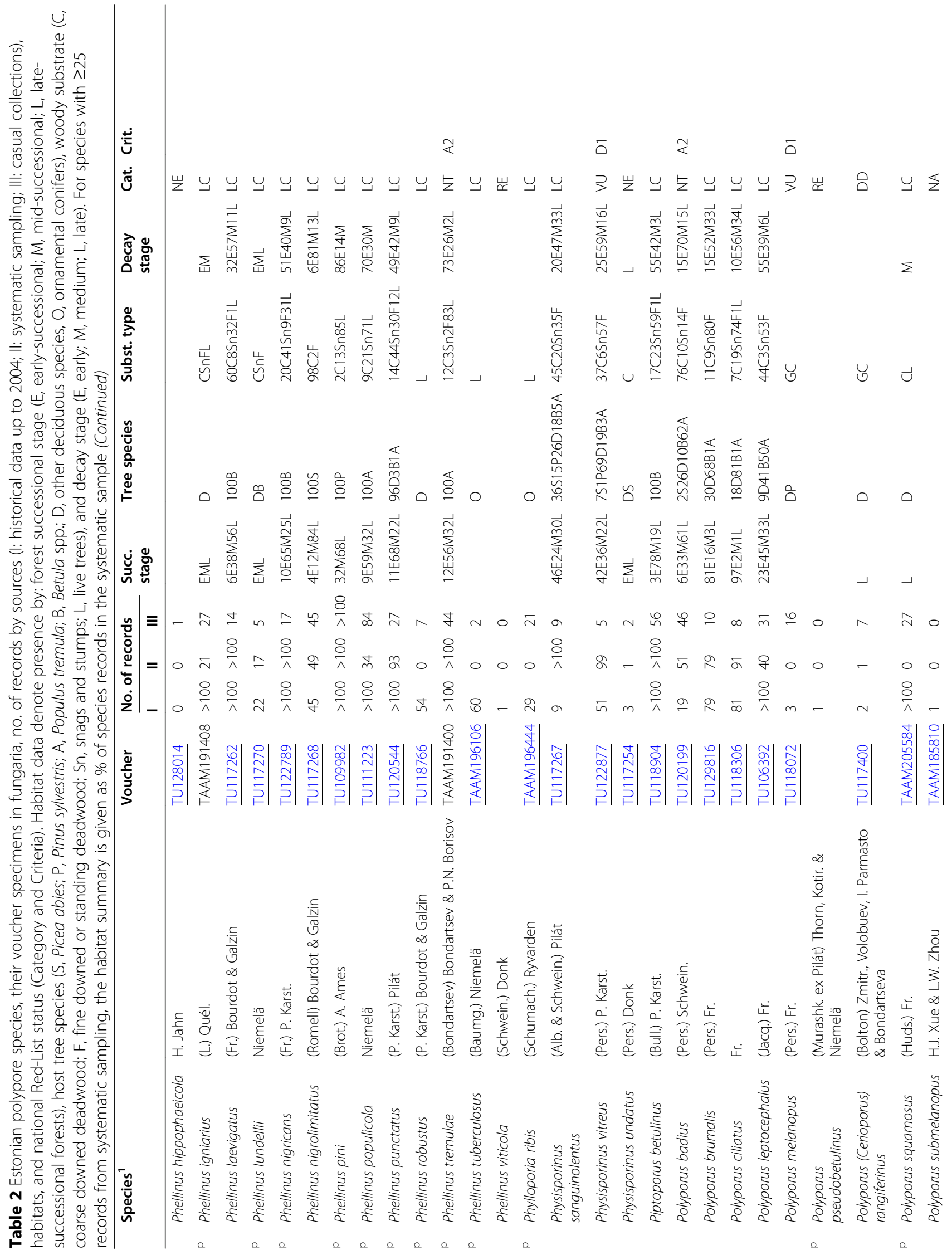




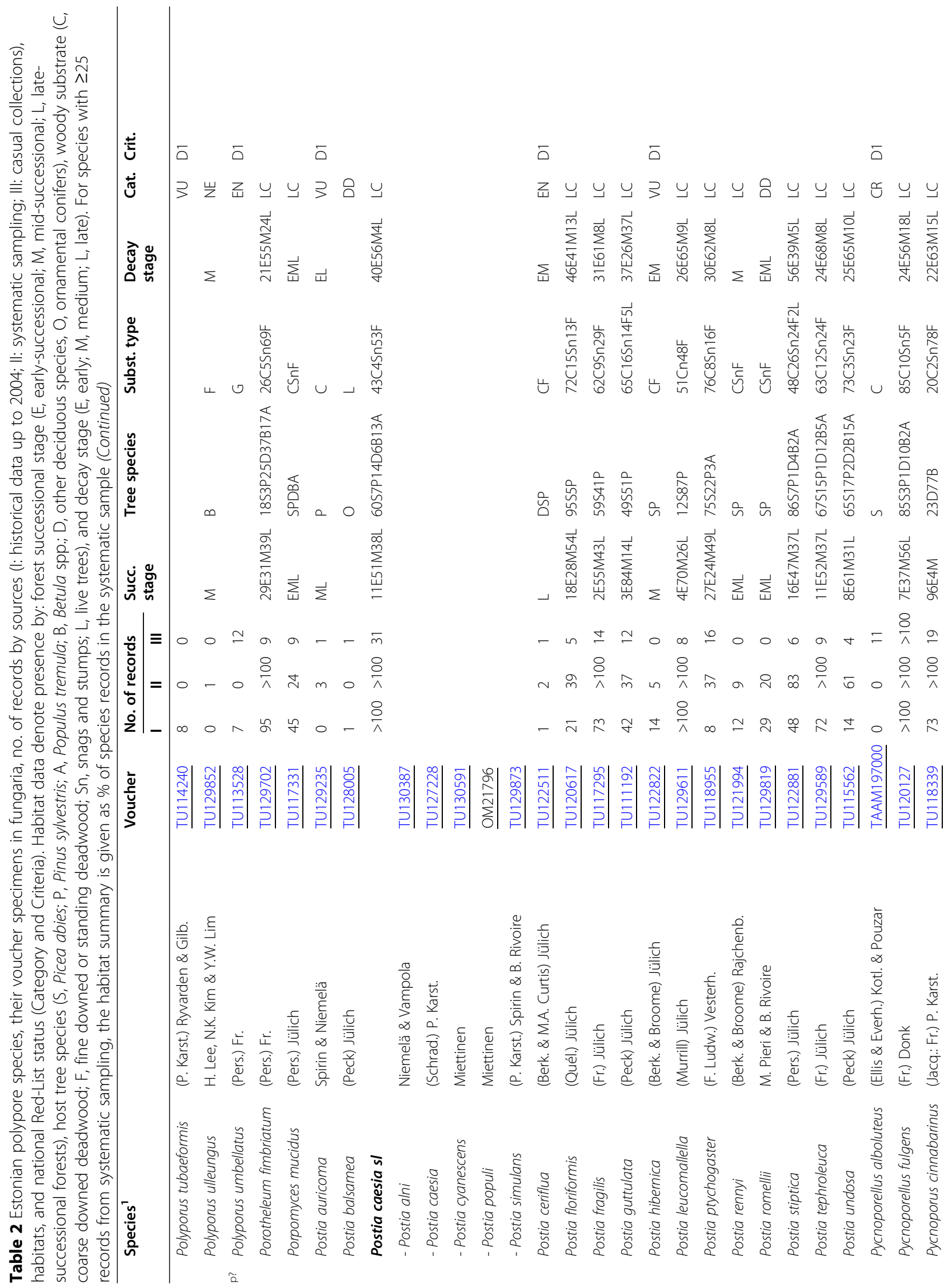




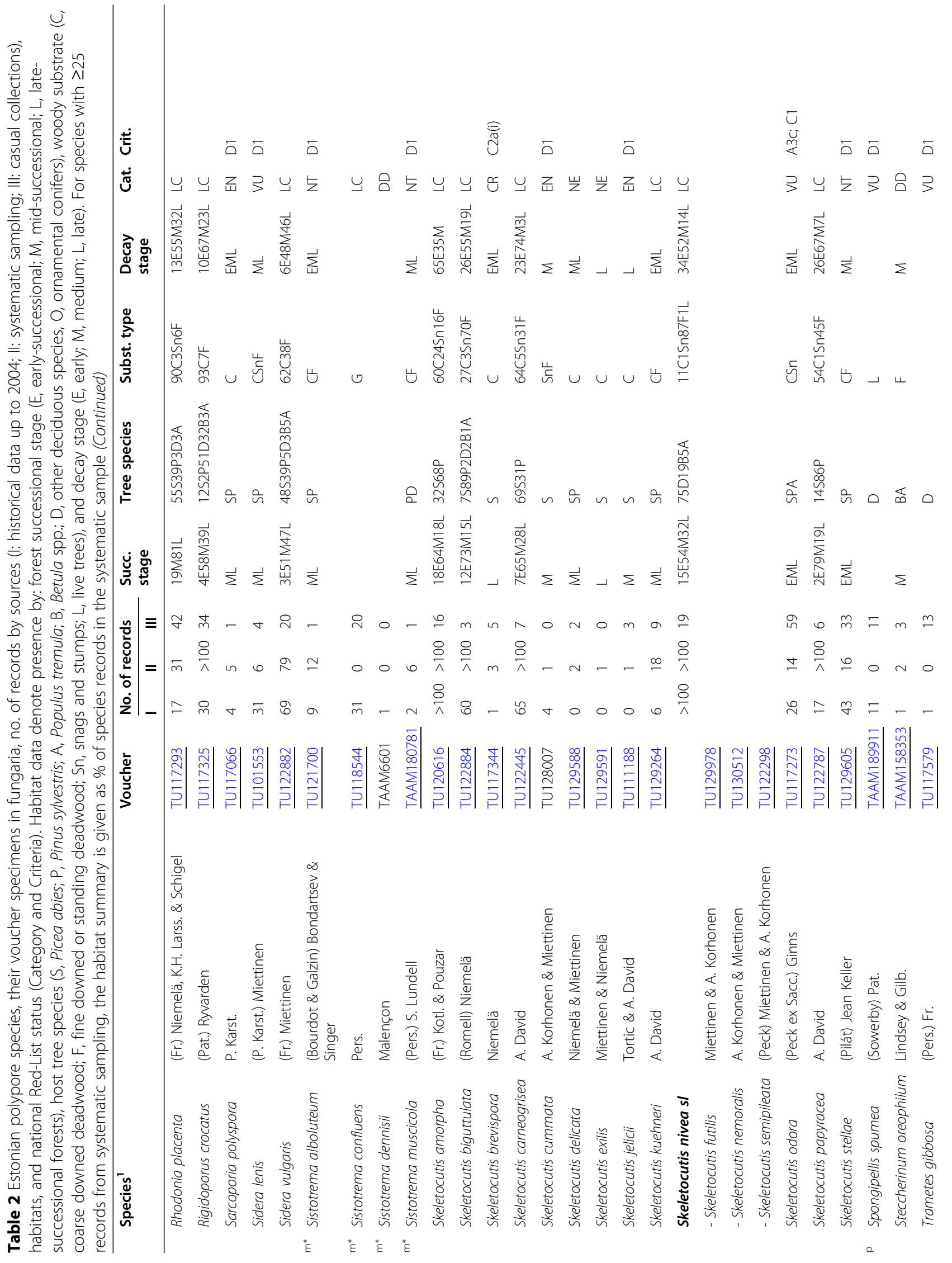




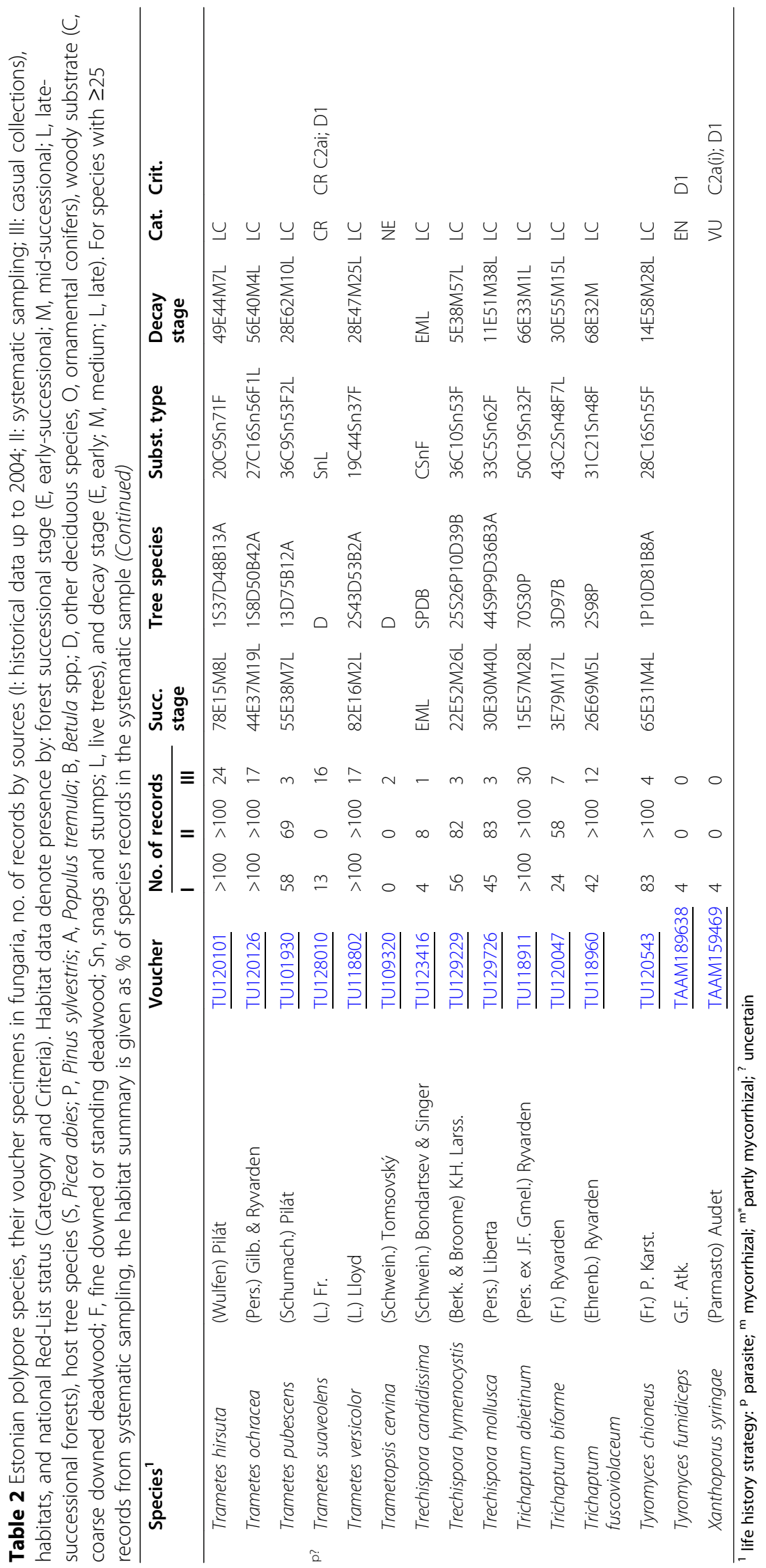


LSU regions. To avoid rooting with distant taxa and producing arbitrary branching orders, their phylogenetic trees were centrally rooted. We organized the sequences as Maximum Likelihood (ML) phylogenies based on IQ-TREE (version 1.2.2; Nguyen et al. 2015), 1000 bootstrap replicates and the 'best-fitted model'. Collection data for the examined Estonian specimens in difficult/unresolved species groups and the GenBank or UNITE accession numbers of their ITS and LSU sequences are presented in Additional file 3, data for public reference sequences from elsewhere are in Additional file 4. The final alignments for all data sets were stored in TreeBASE (http://www.treebase.org; accession number 25415).

Analysing polypore assemblages along habitat gradients Primary data for assessing correspondence between polypore assemblages and habitat gradients were the systematic surveys in stands $>20$ years old (datasets IIa-IIc in Table 1). We categorized the stands into 'habitat types' according to: (1) site-type group - proxy of soil nutrient and humidity combinations (Lõhmus 1984, Additional file 1); (2) tree canopy composition class Picea abies forests and Picea-deciduous mixedwood; Pinus sylvestris forests and Pinus-deciduous mixedwood; deciduous forests ( $\geq 80 \%$ deciduous species); and (3) old stands (dominant tree layer $>100$ years) vs. other stands. We then compiled species lists for each habitat type by pooling species data from all stands belonging to this type. Such approach allowed us to address relative importance of permanent (soil) and temporary variation (tree composition and successional stage) for polypore assemblages. We did not analyse the distinct post clear-cut assemblages that have been addressed in original studies (Lõhmus 2011, Runnel \& Lõhmus 2017); the species found in such early-successional stands can be distinguished in Table 2.

Additionally, we compiled species lists for bog and heath forests, parks and wooded meadows, which have not been systematically surveyed. We used casual records extracted from PlutoF database and Parmasto (2004), relying on original habitat annotations (these habitat types are easily distinguishable); we nevertheless double-checked all such records that had co-ordinates against the Estonian soil map. Tree composition and age were not specified for these additional data, but heath and bog forests in Estonia are typically Pinus sylvestris stands, while most parks and wooded meadows characteristically have old deciduous trees.

Overlaps of species lists among site-type groups were visualized with Euler proportional circle diagrams (eulerr package; Larsson 2018). For assemblage analyses along habitat gradients, we first omitted all species that had been recorded from a single habitat type (a combination of 1-3 above). This retained data on 157 polypore species with 23,362 original records and 54 habitat types. We then recoded species' record numbers for a threeclass scale ( 0 , no records; 1 , one record; $2,>1$ records) as a compromise between observation bias in raw record numbers (resulting from varying habitat coverage and species detectability) and the presence-absence scale's emphasis on rare species.

To illustrate how assemblage composition varies among habitat types, we used non-metric multidimensional scaling (NMDS; vegan package in R, Oksanen et al. 2016). The environmental matrix comprised three categorical variables: site-type group (ten groups; Additional file 1), soil fertility (two classes: fertile vs poor/ thin), and tree species composition (three classes, see above). The analyses were run using the Bray-Curtis dissimilarity index with random starting configurations; searching for two-dimensional solutions, and rotating the final solution to depict the largest variance of site scores on the first axis. Assemblage differences were tested separately for each environmental variable using Multi-Response Permutation Procedures (MRPP) with Bray-Curtis dissimilarity index, and Bonferroni corrected $p$-values.

\section{Substrate analyses}

We followed the concept of functional traits as presented by Dawson et al. (2019) and categorized species mostly according to Niemelä (2016). We first divided the species between strictly or facultatively ectomycorrhizal and wood-inhabiting life-strategy groups. The wood-inhabiting group was further divided by: (a) typical colonization time - parasites of live trees ('necrotrophs' sensu Dawson et al. 2019), early-decayer (most records on trees of decay stage I-II) and late-decayer saprotrophs (stage III-V); and (b) physical decay strategy white-rot and brown-rot producing species. The saprotrophs include some polypores that are frequent on very fine debris, and some 'follower' species that require wood decayed by other parasitic or saproxylic basidiomycetes (Holmer et al. 1997, Niemelä 2016).

We pooled all the available polypore records on naturally developed woody substrates, excluding building timber for which we only report the state of the knowledge. The records are from the datasets I-IIIa (Table 1) and, for Juniperus communis, as summarized by Sell \& Kotiranta (2011). Host tree species have been indicated in all these datasets. We additionally distinguished the main woody fractions and decay stages - those data mostly originate from the systematic surveys (datasets IIa-d). We re-coded the decay stages I-II sensu Renvall (1995) as 'early', III as 'medium', and IV-V as 'late'; in the latter we also included casual records describing the wood as "extremely decayed". Fine woody debris (FWD) includes 
both fallen and standing dead wood items $<10 \mathrm{~cm}$ in diameter at the basidiome location.

Based on the distribution of records among all substrate categories, we distinguished regularly occurring and specialist polypores for a substrate category as follows. 'Regular' species, either: had $\geq 5 \%$ records on that substrate category of the species' total of $\geq 40$ records in Estonia, or had $>1$ records there of its total of $<40$ records, or accounted for $\geq 5 \%$ of all polypore records in that substrate category. 'Specialists' were a subset of regular species, which had $>2$ records from a particular substrate category and this formed either $\geq 90 \%$ of all Estonian records of that species, or all records if the total number of records was 3-9.

Similarity of polypore species composition of native host tree species was further explored with hierarchical cluster analysis based on presence-absence data, BrayCurtis dissimilarity measure and the average linkage method ( $r$ package vegan; Oksanen et al. 2016). Because presence-absence data would over-emphasize atypical substrates, only polypores occurring regularly on each tree species ( $\geq 5 \%$ of total records in the tree or polypore species) were included in this analysis.

\section{RESULTS}

\section{Estonian polypore diversity}

Parmasto (2004) reported 212 polypore species in Estonia, of which 198 can be currently considered accepted, although several have been subdivided on a larger geographical scale (e.g. Antrodia crassa, Antrodia sitchensis, Polyporus tuberaster, Postia sericeomollis and Skeletocutis nivea s. str. are not known in Estonia). Six of those species are now listed as Regionally Extinct based on the lack of records for > 50 years: Antrodia heteromorpha, Diplomitoporus crustulinus, Inonotopsis subiculosa, Inonotus dryadeus, Phellinus viticola, and Polyporus pseudobetulinus (Table 2). Probably, they were already extinct in 2004. Excluded species include seven formerly recognized taxa (Antrodia albida, Ceriporia subreticulata, Phellinus cinereus, Postia lactea, Sistotrema albopallescens, Skeletocutis subincarnata, and Trametes velutina) that are now merged with other species known in Estonia. We also excluded two putative new Phellinus species on Parmasto's list (status as independent species not supported). Five species were excluded because the historical material had been misidentified: Antrodiella canadensis, Ganoderma adspersum, and Skeletocutis alutacea (all specimens checked), and Postia lateritia and Trichaptum laricinum (most specimens checked, none confirmed). Two species, Aurantiporus priscus (a part of "Hapalopilus salmonicolor" records in Parmasto 2004) and Ganoderma carnosum, remain on our list based on Parmasto's original identifications; the collections have survived but we failed to obtain sequences from this old material.

As of July 2019, the list comprises 221 verified extant species (Table 2), including 11 with no post-2004 records (Anomoloma albolutescens, Antrodiella parasitica, Aurantiporus priscus, Ganoderma carnosum, Oxyporus ravidus, Perenniporia tenuis, Polyporus submelanopus, $P$. tubaeformis, Sistotrema dennisii, Tyromyces fumidiceps, and Xanthoporus syringae). Seventeen extant species have been only recorded once, and six only twice (Table 2); 11 of these extremely rare species were recorded in 2005-18. Based on the numbers of accepted species, singletons and doubletons, the Chao (1987) estimate for expected species richness is 245 extant species. Additionally, there are records of at least 20 lineages that may deserve species status (see under Difficult species below; Table 3). Three species are, according to current records, restricted to the West-Estonian, and nine to the East-Estonian geobotanic regions (only species with $>1$ records considered).

Species were added to the 2004 list for three reasons (* solely from casual collections) and include two species newly reported for Europe (Polyporus submelanopus, $P$. ulleungus):

(1) Ten established species were found in nature for the first time after 2004: Coltricia cinnamomea, $C$. confluens, Fibroporia norrlandica, Obba rivulosa, Perenniporia narymica, Phellinus hippophaeicola", Postia auricoma, Pycnoporellus alboluteus", Skeletocutis jelicii, and Trametopsis cervina*. Eight of these (excluding F. norrlandica and O. rivulosa) are easy to find and identify, and may thus constitute true recent additions to the Estonian mycota.

(2) Nine species have been distinguished from other species present in the area and confirmed or likely to be present in the pre-2004 material of the collective species: Ceriporia bresadolae (from C. purpurea), Hapalopilus aurantiacus and $H$. ochracolateritius (from "H. salmonicolor" sensu Parmasto 2004), Postia cyanescens, P. simulans and P. populi (from P. alni and P. caesia), and Skeletocutis futilis, S. nemoralis and S. semipileata (from S. nivea s. str. that is not known in North Europe).

(3) Ten species, now confirmed in Estonia, have been described or reinstated only after 2004. Of these, Antrodia leucaena has been confirmed by us also in the Estonian pre-2004 material, and Polyporus submelanopus" only in that material. The other species are: Aporpium macroporum, Ceriporia aurantiocarnescens, C. torpida, Junghuhnia 
Table 3 Lineages of unnamed and/or collective polypore species in Estonia. Freq - no. of records in Estonia $\left(^{*} 1 ;^{* *} 2-5 ;^{* * *}>5\right)$

\begin{tabular}{|c|c|c|c|c|c|c|c|c|}
\hline \multirow[b]{2}{*}{ Taxon } & \multicolumn{4}{|c|}{ Vouchers from Estonia } & \multicolumn{3}{|c|}{ Best match from outside Estonia } & \multirow[b]{2}{*}{ Freq. } \\
\hline & Lineage & Voucher ID & $\begin{array}{l}\text { UNITE SH code at } \\
1.5 \% \text { threshold } \\
\text { level }\end{array}$ & $\begin{array}{l}\text { Similarity \% (no. } \\
\text { of variable/total } \\
\text { sites) }\end{array}$ & Annotation & $\begin{array}{l}\text { GenBank } \\
\text { no. }\end{array}$ & $\begin{array}{l}\text { Similarity to voucher } \\
\% \text { (no. of variable/ } \\
\text { total sites) }\end{array}$ & \\
\hline \multirow[t]{2}{*}{ Antrodiella faginea } & L1 & TU130324 & SH1600328.08FU & \multirow[t]{2}{*}{$99 \%(6 / 549$ BP) } & A. faginea (CZ) & AF126885 & $100 \%(0 / 549 \mathrm{BP})$ & $* * *$ \\
\hline & L2 & TU130481 & SH1600328.08FU & & A. faginea (RU) & KU726586 & $100 \%(0 / 547 \mathrm{BP})$ & *** \\
\hline \multirow[t]{2}{*}{ Byssoporia terrestris } & L1 & TU130505 & SH1542891.08FU & \multirow[t]{2}{*}{ 79\% (124/583 BP) } & B. terrestris (FI) & UDB031621 & $99 \%(2 / 576 \mathrm{BP})$ & * \\
\hline & L2 & TU130449 & SH1629432.08FU & & B. terrestris (SE) & EU118608 & $83 \%(101 / 587 \mathrm{BP})$ & $* *$ \\
\hline \multirow[t]{2}{*}{ Ceriporia excelsa } & L1 (s. typi) & TU115577 & SH2141340.08FU & \multirow[t]{2}{*}{ 98\% (15/909 BP) } & C. excelsa (US) & MH858306 & $100 \%(0 / 598 \mathrm{BP})$ & *** \\
\hline & L2 & TU124431 & SH1510726.08FU & & Ceriporia sp. (US) & KP135050 & $99 \%(2 / 598$ BP) & * \\
\hline \multirow[t]{2}{*}{ Ceriporia viridans } & L1 (s. typi) & TU130515 & SH1510720.08FU & \multirow[t]{2}{*}{ 97\% (27/902 BP) } & C. viridans s str. (FI) & KX236481 & $99 \%(4 / 549$ BP) & *** \\
\hline & L2 & TU130057 & SH1510723.08FU & & C. viridans s str. (FI) & KX236481 & $97 \%(23 / 549 \mathrm{BP})$ & $* * *$ \\
\hline \multirow{2}{*}{$\begin{array}{l}\text { Ceriporiopsis } \\
\text { pseudogilvescens }\end{array}$} & L1 (s. typi) & TU122449 & SH1543621.08FU & \multirow[t]{2}{*}{ 99\% (2/597 BP) } & C. pseudo-gilvescens (CN) & KU509523 & 100\% (0/597 BP) & *** \\
\hline & L2 & TU129148 & SH1543621.08FU & & C. resinascens (SK) & FJ496679 & $99 \%(2 / 597)$ & $* *$ \\
\hline \multirow{4}{*}{$\begin{array}{l}\text { Coltricia } \\
\text { cinnamomea }\end{array}$} & L1 & TU110786 & SH1651067.08FU & \multirow{4}{*}{$\begin{array}{l}76-99 \%(8-151 / \\
574 \text { BP) }\end{array}$} & C. cinnamomea $(\mathrm{CN})$ & KY693732 & $88 \%$ (72/584 BP) & $* *$ \\
\hline & L2 & TU113488 & SH1651067.08FU & & C. cinnamomea (CN) & KY693732 & $87 \%(73 / 580 \mathrm{BP})$ & $* *$ \\
\hline & L3 & TU106861 & SH1611633.08FU & & Coltricia sp. (MX) & MG966155 & $98 \%(12 / 595$ BP) & * \\
\hline & $\llcorner 4$ & TAAM196949 & SH1651068.08FU & & C. cinnamomea $(\mathrm{CN})$ & KY693729 & $90 \%(63 / 608$ BP) & * \\
\hline \multirow[t]{3}{*}{ Coltricia perennis } & L1 & TU106858 & SH1554196.08FU & \multirow{3}{*}{$\begin{array}{l}86-99 \%(8-76 / \\
553 \text { BP) }\end{array}$} & C. perennis (US?) & DQ234560 & $99 \%$ (8/541 BP) & * \\
\hline & L2 & TU110835 & SH1554196.08FU & & C. perennis (US?) & DQ234560 & 100\% (0/538 BP) & * \\
\hline & L3 & TU106860 & SH1554198.08FU & & C. perennis (FI) & MF319057 & $99 \%$ (2/543 BP) & $* *$ \\
\hline \multirow{2}{*}{$\begin{array}{l}\text { Physisporinus } \\
\text { sanguinolentus }\end{array}$} & L1 & TU122889 & SH1558568.08FU & \multirow[t]{2}{*}{ 97\% (19/543 BP) } & P. furcatus (RU) & KY131853 & $98 \%(12 / 532 \mathrm{BP})$ & ** \\
\hline & L2 & TU129782 & & & P. furcatus (CN) & KY131856 & $99 \%$ (5/536 BP) & * \\
\hline \multirow[t]{4}{*}{ Physisporinus vitreus } & L1 & TU130068 & SH1615294.08FU & \multirow{4}{*}{$\begin{array}{l}94-99 \%(2-27 / \\
464 \text { BP) }\end{array}$} & P. sanguinolentus (SE) & $J X 109843$ & $99 \%$ (5/541 BP) & *** \\
\hline & L2 & TU129958 & SH1615294.08FU & & P. sanguinolentus (SE) & $J \times 109843$ & $99 \%(4 / 541$ BP) & $* *$ \\
\hline & L3 & TU130572 & SH1615294.08FU & & P. sanguinolentus (SE) & JX109843 & $99 \%(1 / 463 \mathrm{BP})$ & $* *$ \\
\hline & $\llcorner 4$ & TU122877 & SH1615296.08FU & & P. sanguinolentus (SK) & FJ496671 & $100 \%(1 / 539 \mathrm{BP})$ & $* *$ \\
\hline \multirow[t]{3}{*}{ Sidera spp. } & L1 (annual) & TU122801 & SH1544622.08FU & \multirow{3}{*}{$\begin{array}{l}80-86 \% \%(90- \\
176 / 871 \text { BP) }\end{array}$} & Sidera sp. (US) & KP814157 & 97\% (15/597 BP) & $* *$ \\
\hline & L2 (annual) & TU129576 & SH1612214.08FU & & Schizopora sp. (US) & MF161274 & $99 \%$ (4/587 BP) & $* * *$ \\
\hline & L3 (perennial) & TU122545 & SH1540362.08FU & & Sidera vulgaris (AU) & FN907922 & $96 \%(12 / 280 \mathrm{BP})$ & $* * *$ \\
\hline \multirow{2}{*}{$\begin{array}{l}\text { Sistotrema } \\
\text { alboluteum }\end{array}$} & L1 & TU121700 & SH1506830.08FU & \multirow[t]{3}{*}{ 95\% (28/538 BP) } & S. aff. alboluteum (US) & KP814533 & $94 \%(30 / 538$ BP) & $* *$ \\
\hline & L2 & TU130503 & SH1506832.08FU & & S. aff. alboluteum (US) & KP814533 & $99 \%$ (2/534 BP) & * \\
\hline \multirow[t]{4}{*}{ Sistotrema muscicola } & L1 & TU130567 & SH1539308.08FU & & Sistotrema sp. (US) & KP814242 & $91 \%(48 / 533$ BP) & $* *$ \\
\hline & L2 & TAAM180781 & SH1506835.08FU & $85-94 \%(30-72 /$ & S. muscicola (FI) & AJ606040 & $99 \%(1 / 475$ BP) & * \\
\hline & L3 & TAAM202939 & SH1539286.08FU & & Sistotrema sp. (US) & KP814241 & $91 \%(51 / 537$ BP) & $* *$ \\
\hline & $\llcorner 4$ & TU130466 & SH1539297.08FU & & Sistotrema sp. (US) & KP814241 & $91 \%(47 / 525$ BP) & * \\
\hline $\begin{array}{l}\text { Skeletocutis sp. } \\
\text { (kuehneri group) }\end{array}$ & & TU128024 & SH1541633.08FU & & Skeletocutis chrysella (FI) & FN907916 & $95 \%(28 / 583$ BP) & * \\
\hline
\end{tabular}

autumnale, Leptoporus erubescens, Polyporus ulleungus, Skeletocutis delicata, and S. exilis.

\section{Difficult species}

We distinguished 13 species groups of Estonian polypores, for which the assessment of population status and ecology was complicated (details in Additional file 5). In most cases, the problem was unresolved taxonomy: molecular data revealed that the prevailing species concept included cryptic lineages (Table 3, Additional file 3), some with documented ecological differences.
Specifically, Estonian specimens referred to in Table 2 by the accepted names Antrodiella faginea, Byssoporia terrestris, Ceriporia excelsa, C. viridans, Ceriporiopsis pseudogilvescens, Physisporinus sanguinolentus, Sidera vulgaris, and Sistotrema alboluteum represented two distinct lineages each, and those identified as Coltricia cinnamomea, C. perennis, Physisporinus vitreus and Sistotrema muscicola at least three lineages each. Additionally, we sequenced an undescribed lineage related to Skeletocutis kuehneri/brevispora, and found that the Estonian specimens of Sidera lenis do not match with its 
prevailing species concept. In the Ceriporiopsis resinascens / C. pseudogilvescens lineages, the main morphological characteristics represented a continuum and some specimens had ITS copies from multiple lineages. The abundance of records or their habitat diversity indicated no apparent conservation concern in any lineages of Antrodiella faginea and Ceriporia viridans, while at least one likely threatened lineage was detected in Ceriporia excelsa, Coltricia cinnamomea, C. perennis, and Sidera vulgaris.

Another, sometimes combined problem was the lack of stable morphological character combinations to enable species identification in recently revised species groups; this introduced large uncertainty to interpreting historical collections and observations. For example, the species earlier known as Postia caesia, P. alni, P. leucomallella, and Skeletocutis nivea have been considered easily identifiable in the field and their mostly observational data cannot be ascribed to the recently segregated species. Also, sequencing of European fungarium specimens of black-stiped Polyporus collections is recommended due to high likelihood of finding species traditionally not considered to occur in Europe.

\section{Functional traits}

Most Estonian polypore species produce annual basidiomes, but in 51 species these survive for at least 2-3 years (usually $>3$ years in 33 of these). The prevailing life strategy is saprotrophy, with at least 12 species being follower species of other wood-inhabiting (parasitic or saprotrophic) polypores (Table 2). Based on systematic surveys (datasets IIa-c; Table 1), basidiomes of the follower species are found 1-3 orders of magnitude less frequently than their predecessor species. A wide variation can occur in the same predecessor species, e.g., the Estonian records among the followers of Trichaptum abietinum range from one (Antrodiella parasitica) to 380 (Skeletocutis carneogrisea).

Thirty-four polypore species are parasites of live trees or shrubs, but usually continue living as saprotrophs after death of the host-tree. Three parasitic species (Heterobasidion annosum, H. parviporum, and Phellinus tremulae) are considered economically important forest pathogens in Estonia. Thirteen polypore species are considered strictly or facultatively ectomycorrhizal (Albatrellus, Boletopsis, Coltricia, and Sistotrema) (Table 2). Distinctly among functional groups, mycorrhizal polypores are most diverse in dry and low-productive forest types: eight species inhabit alvar forests (on calcareous soil), eight dry boreal, and seven boreal heath forests (on sandy soil). In contrast, only three mycorrhizal species have been found in eutrophic sites, five in mesoeutrophic, and three in swamp forests.

\section{Habitat types and assemblages}

Among the three broad forest successional stages (Table 2 ), the largest numbers of species have been recorded in mid-successional forests (146; incl. 16 parasitic and five wholly or partially mycorrhizal species) and latesuccessional forests (146; incl. 19 parasitic and eight wholly or partially mycorrhizal species). The largest numbers of threatened species were found in latesuccessional (38 species) and mid-successional forests (34). Based on systematic surveys (Table 1: datasets IIa-c), the most abundant species in mid- and latesuccessional forests are Fomitopsis pinicola (10.5\% of 18,026 records), Trichaptum abietinum (8.5\%), and Fomes fomentarius (7.4\%). In post clear-cut (early-successional) stands, most abundant are Gloeophyllum sepiarium (9.0\% of 4939 records), F. pinicola (7.5\%), and Trametes hirsuta (6.4\%). However, these proportions are underestimates compared with rarer species, since our sampling included up to ten records of each species per plot (see Methods).

Estonian polypore assemblages in $>20$ year-old forests are primarily organized along the soil (site type) and tree species composition gradients (Fig. 2; Additional file 6). The first ordination axis broadly distinguished assemblages on fertile soils from those on poor soils (sandy, thin calcareous, or peat soils) (MRPP test: $\mathrm{A}=0.08, p<$ 0.001). The second axis ranged from deciduous- to Pinus-dominated stands, with Picea-dominated forests in the middle (MRPP tests: $\mathrm{A}=0.07-0.09, \mathrm{p}<0.001$, for the contrasts with Pinus-dominated sites; A $=0.03, p=0.02$, for Picea- vs deciduous-dominated sites). These two gradients overshadowed soil moisture effects; e.g., Pinusdominated sites with contrasting moisture conditions (dry alvar forests, wet drained peatland, and bog forests) were positioned close to each other, but clearly apart from moist sites dominated by either Picea or deciduous trees (Fig. 2).

Across natural forest types, polypore assemblages formed a continuum in the ordination space (Fig. 2), i.e., only distant types differed significantly from each other. For example, the assemblages in eutrophic sites appeared close to those in meso-eutrophic or swamp sites (MRPP: $\mathrm{A} \leq 0.01$, Bonferroni corrected $p>0.1$ ), but differed from all other forest site-type groups $(A=0.09$ $0.14, p<0.033$ in all comparisons). Such a pattern is also revealed on the Euler diagrams: increasing proportions of species common to more similar site types, but a relatively small number of generalists across all habitat types (Fig. 3A,B middle section). The most distinct assemblages in natural forests were in alvar forests that differed from all others $(A=0.08-0.17, p<0.034$ in all comparisons), except perhaps heath forests $(A=0.13$, $p=0.067$ ). Specific species in our sample of alvar forests were the ectomycorrhizal Albatrellus citrinus and 

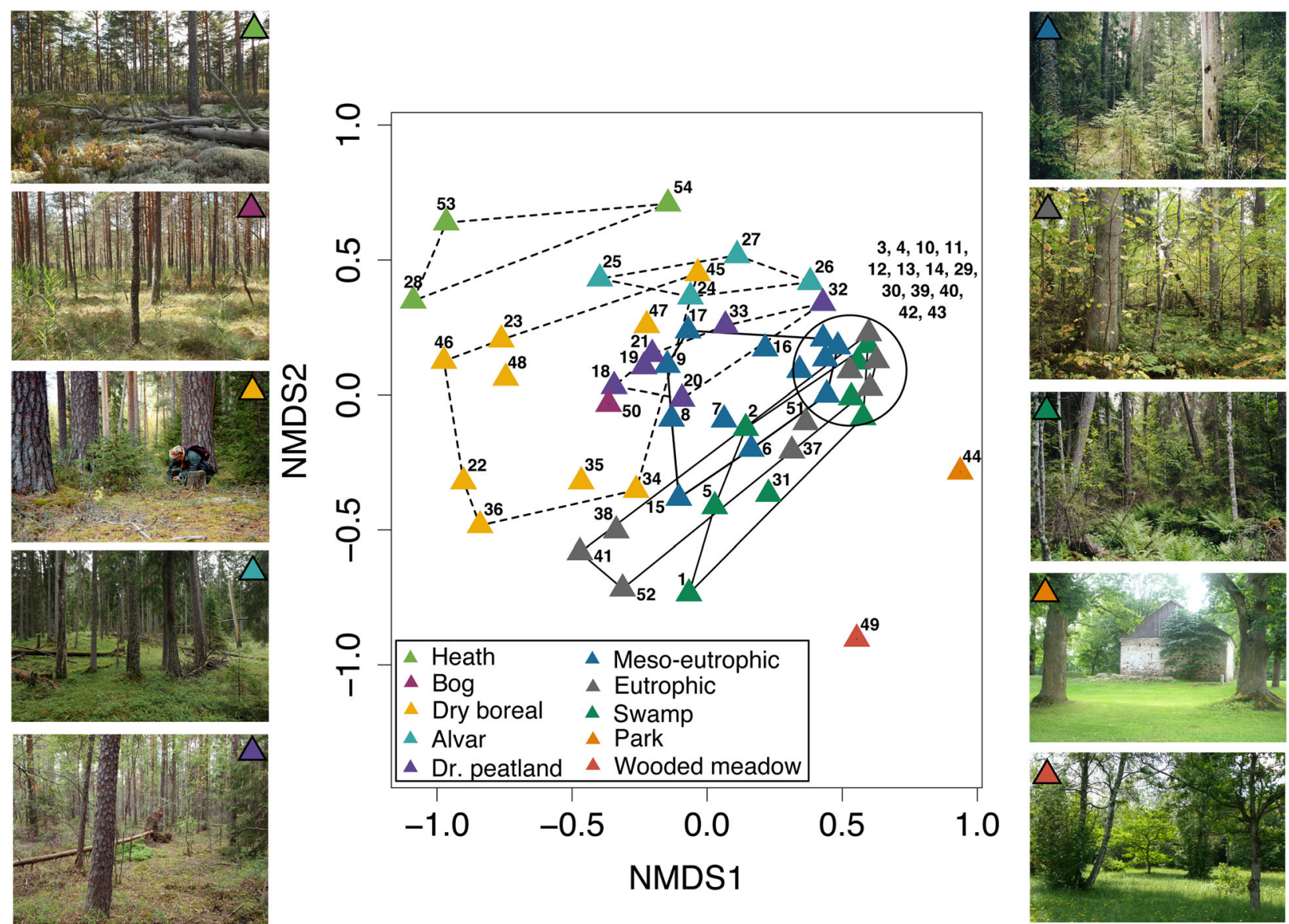

Fig. 2 Non-metric multidimensional scaling (NMDS) ordination diagram of polypore assemblages in 54 site-type group $\times$ tree species $\times$ age combinations (points; the number codes explained in Additional file 1). The two-dimensional solution with the final stress value of 0.166 is shown. The symbols denote woodland types; photo credits: E. Lõhmus, P. Lõhmus, A. Palo. Note the three woodland types represented by a single pooled species list: parks (44), wooded meadows (49) and bog forests (50)

Boletopsis leucomelaena, and saprotrophic Anomoloma myceliosum and Skeletocutis jelicii. The largest number of habitat-specific species inhabit natural forests on nutrient-rich soils: 21 such species in eutrophic and swamp sites combined, including 18 extremely rare or threatened species (e.g. Picea-inhabiting Amylocystis lapponica, Antrodia piceata, and Skeletocutis brevispora; Populus-inhabiting Aporpium macroporum, Junghuhnia fimbriatella, and Inonotus rheades).

All anthropogenic woodland types (drained peatland forests, parks, and wooded meadows) hosted distinct polypore assemblages (Fig. 2). Drained peatland forests revealed two specific species (Postia auricoma; Antrodia macra) and their full assemblages resembled most those in dry boreal (MRPP test: $\mathrm{A}=0.04, p=0.060$ ) or mesoeutrophic forests $(\mathrm{A}=0.04, p=0.069)$, while all other forest site-type groups were dissimilar $(\mathrm{A}=0.09-0.11$, $p<0.035$ ). Parks and wooded meadows were each represented with one pooled species list in our data; thus we could not formally test their assemblage differences. However, as illustrated by the Euler diagrams (Fig. 3), parks had the largest number of specific species (13) and seven polypores are largely confined to large oaks (Quercus robur) and elms (Ulmus glabra) typical of parks and wooded meadows (Daedalea quercina, Fistulina hepatica, Grifola frondosa, Inonotus ulmicola, Phellinus robustus, Perenniporia medulla-panis, and Polyporus umbellatus). Some of the latter species also inhabit the rare natural oak stands in Estonia, which have not been systematically surveyed; casual data show that such stands additionally host some highly threatened species (Aurantiporus croceus and Haploporus tuberculosus).

\section{Woody substrates and substrate specificity}

Host tree species data were available for 204 Estonian polypore species that inhabit natural woody substrates (Table 4). Sixty (29\%) of these species can be considered tree-species specialists. Picea abies stands out with most 


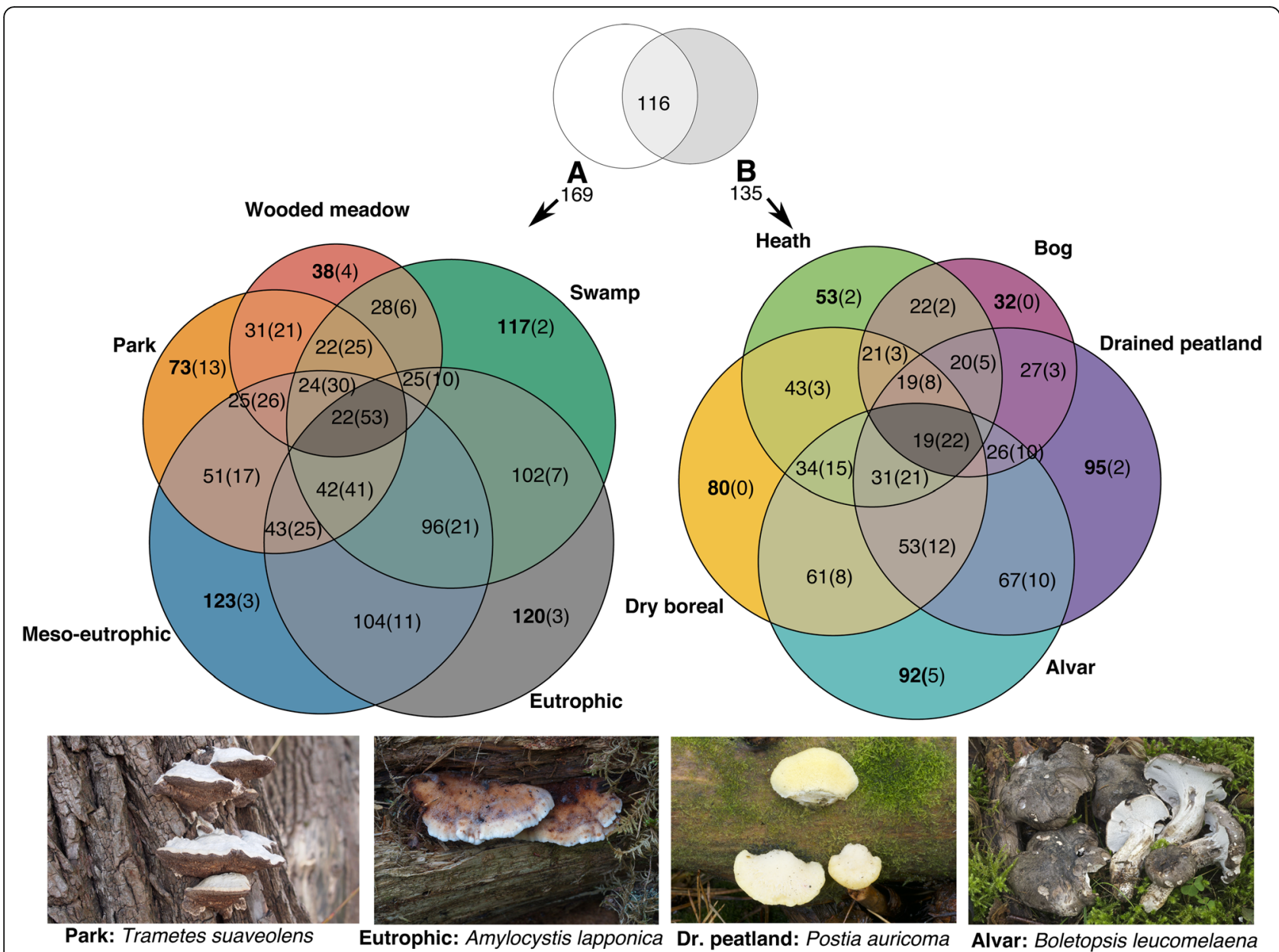

Fig. 3 Euler diagrams of 189 polypore species (including singletons) found in different combinations of Estonian habitat types on fertile soils (a) and poor soils (b). The numbers before parentheses indicate species found in every habitat type included in the combination; the numbers in parentheses indicate species that have not been found elsewhere (considering both types of soils); examples are illustrated on the photos (Photo credit: V. Liiv, E. Lõhmus, O. Miettinen, U. Ojango). The habitat combinations shown were extracted by the eulerr package (Larsson 2018); see Additional file 7 for statistics of other habitat combinations

associated species (108) and threatened species (40), and one-third of all specialist species (20, including 11 threatened species). The other polypore-rich trees include Pinus sylvestris and Betula spp. (the most abundant tree species in Estonia) and Populus tremula. Quercus robur is the only other tree species with several specialist polypores recorded. In contrast, small-sized woody species - shrubs and trees, which mostly stay in forest understories - generally lack specialist polypores (Botryodontia millavensis on Juniperus communis being the only exception). Phellinus tuberculosus and Phylloporia ribis are two specialized polypores so far only reliably recorded on fruit trees and shrubs in gardens (Table 4), although both have potential congenerous wild hosts in woodlands (Prunus padus/spinosa and Ribes spp., respectively).
Among 152 wood-inhabiting species recorded $>10$ times in Estonia, 52 (34\%) have been found on 1-2 tree species, $50(33 \%)$ on $3-7$ tree species, and 49 (32\%) on at least 8 tree species. Bjerkandera adusta (recorded on 18 host tree species), Trametes hirsuta (18), and T. versicolor (16) had the widest host range. Host-tree specificity differs among functional groups: parasitic polypores are most often restricted to 1-2 tree species (Fig. 4a), and white-rot producers are more often generalists than brown-rot producers (Fig. $4 b)$.

By their polypore assemblages, native woody hosts form three main clusters that largely follow taxonomic divisions (Fig. 5): (1) the two Estonian conifer trees of Pinaceae; (2) common soft-wooded deciduous trees, including all native trees of Betulaceae (Betula spp. and 
Table 4 Numbers of polypore species recorded on naturally developed woody substrates in Estonia. The most species rich substrate in each substrate category (column) is indicated with bold script. Species counts by substrate type and decay stage may not correspond to the pooled species count of a tree species since some records lacked detailed substrate data. See Methods for the criteria of 'regular' and 'specialist' species. '-'no information

\begin{tabular}{|c|c|c|c|c|c|c|c|c|c|c|c|}
\hline & & \multicolumn{10}{|c|}{ No. of species (no. of red-listed species: NT-RE) } \\
\hline & & \multicolumn{3}{|c|}{ Substrate types pooled } & \multicolumn{4}{|c|}{ Substrate type } & \multicolumn{3}{|c|}{ Decay stage } \\
\hline & & All & Regular & Specialist & $\begin{array}{l}\text { Fallen } \\
\text { trunk }\end{array}$ & $\begin{array}{l}\text { Snag, } \\
\text { stump }\end{array}$ & FWD & Live tree & Early & Medium & Late \\
\hline \multirow[t]{17}{*}{ Native woody species } & Picea abies & $108(40)$ & $73(26)$ & 20(11) & $101(38)$ & $54(11)$ & $57(13)$ & 13(1) & $66(17)$ & $79(21)$ & $61(17)$ \\
\hline & Populus tremula & $102(23)$ & $58(13)$ & $11(8)$ & $85(21)$ & $44(6)$ & $59(10)$ & $17(3)$ & $56(3)$ & $67(10)$ & $42(11)$ \\
\hline & Betula spp. & $97(18)$ & $67(8)$ & $8(0)$ & $77(12)$ & $58(3)$ & 68(5) & $16(1)$ & $62(4)$ & 75(8) & $69(7)$ \\
\hline & Pinus sylvestris & $89(25)$ & $60(16)$ & $10(1)$ & $77(23)$ & $35(3)$ & $54(11)$ & $8(2)$ & $56(10)$ & $61(15)$ & $40(8)$ \\
\hline & Alnus glutinosa & $71(7)$ & $46(4)$ & 0 & $60(6)$ & $37(3)$ & 48(3) & $9(0)$ & $39(5)$ & $47(4)$ & $40(2)$ \\
\hline & Alnus incana & $54(5)$ & $19(0)$ & 0 & $35(3)$ & $20(0)$ & $32(1)$ & $2(0)$ & $22(1)$ & $23(0)$ & $13(0)$ \\
\hline & Quercus robur & $54(14)$ & $16(5)$ & $6(3)$ & $27(5)$ & $17(2)$ & $17(3)$ & $12(6)$ & $5(0)$ & $3(0)$ & 0 \\
\hline & Salix spp. & $52(7)$ & 14(1) & $1(0)$ & $30(3)$ & $16(2)$ & $32(3)$ & $9(1)$ & $14(2)$ & $21(2)$ & $7(1)$ \\
\hline & Fraxinus excelsior & $50(6)$ & $18(2)$ & 0 & $33(4)$ & $20(1)$ & $25(2)$ & $7(0)$ & $22(1)$ & $27(2)$ & 9(3) \\
\hline & Corylus avellana & $49(3)$ & $17(2)$ & 0 & $22(1)$ & $16(1)$ & $38(3)$ & $5(0)$ & $24(0)$ & $22(2)$ & $15(1)$ \\
\hline & Tilia cordata & $41(1)$ & $10(1)$ & 0 & $24(1)$ & $16(1)$ & $25(0)$ & $7(0)$ & $21(0)$ & $23(1)$ & $14(1)$ \\
\hline & Sorbus aucuparia & $40(2)$ & $7(0)$ & 0 & $18(1)$ & $10(0)$ & $23(1)$ & $4(0)$ & $18(2)$ & $19(0)$ & $8(0)$ \\
\hline & Acer platanoides & $33(4)$ & 10(1) & 0 & $21(2)$ & $14(1)$ & $9(0)$ & $5(1)$ & $9(0)$ & $11(1)$ & $5(0)$ \\
\hline & Ulmus spp. & $30(5)$ & $7(2)$ & $1(1)$ & $14(2)$ & $11(1)$ & $6(0)$ & $5(3)$ & $5(0)$ & $7(1)$ & $1(0)$ \\
\hline & Prunus padus & $19(0)$ & $3(0)$ & 0 & $9(0)$ & $6(0)$ & $4(0)$ & $2(0)$ & $1(0)$ & $3(0)$ & $1(0)$ \\
\hline & Juniperus communis & $16(5)$ & $5(1)$ & $1(1)$ & $4(1)$ & $2(0)$ & $8(2)$ & $1(0)$ & $7(3)$ & $2(1)$ & $2(1)$ \\
\hline & Frangula alnus & $7(0)$ & $1(0)$ & 0 & 0 & $2(0)$ & $5(0)$ & 0 & $6(0)$ & $1(0)$ & $1(0)$ \\
\hline \multirow[t]{4}{*}{ Exotic woody species } & Deciduous & $31(6)$ & $3(1)$ & 0 & $7(1)$ & $7(0)$ & $3(0)$ & $10(2)$ & - & - & - \\
\hline & Fruit trees, bushes & $20(2)$ & $3(0)$ & $2(0)$ & $6(0)$ & $11(0)$ & 0 & $12(2)$ & - & - & - \\
\hline & Coniferous & $14(2)$ & $1(1)$ & 0 & $5(1)$ & $3(0)$ & 0 & $2(1)$ & - & - & - \\
\hline & TOTAL & $204(78)^{*}$ & $175(57)$ & $60(25)$ & $186(67)$ & $134(30)$ & $145(35)$ & $70(16)$ & $139(33)$ & $153(39)$ & $127(30)$ \\
\hline
\end{tabular}

*In addition three species are known from unidentified tree species only

Alnus glutinosa being the most similar host pair) and Populus tremula (a distinct host); and (3) the remaining woody species, with the most distinct assemblages on nemoral hardwoods (Acer, Quercus, and Fraxinus); Salix spp. clustering together with Fraxinus; and a similar host pair of the native trees in Rosaceae - Prunus padus and Sorbus aucuparia.
Coarse downed wood (fallen trunks) is by far the most polypore-rich woody fraction, with the largest number of species found in the medium decay stage (Table 4). This is despite a wider range of host species (including shrubs) providing fine woody debris. Betula spp. differs from other main tree species by distribution of species richness among wood fractions: relatively many species
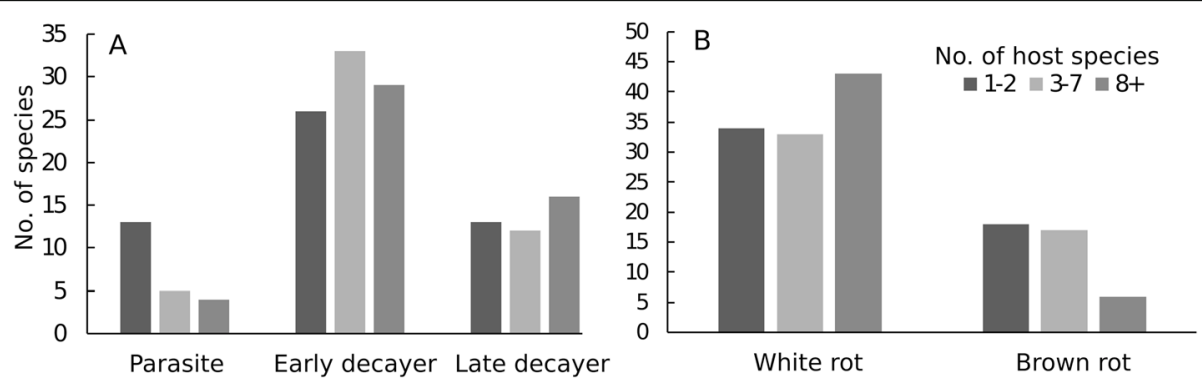

Fig. 4 No. of host tree species listed for wood-inhabiting polypore species with > 10 records in Estonia by life strategy (a) and by decay type (b). The categorization for each species given in Additional file 8 


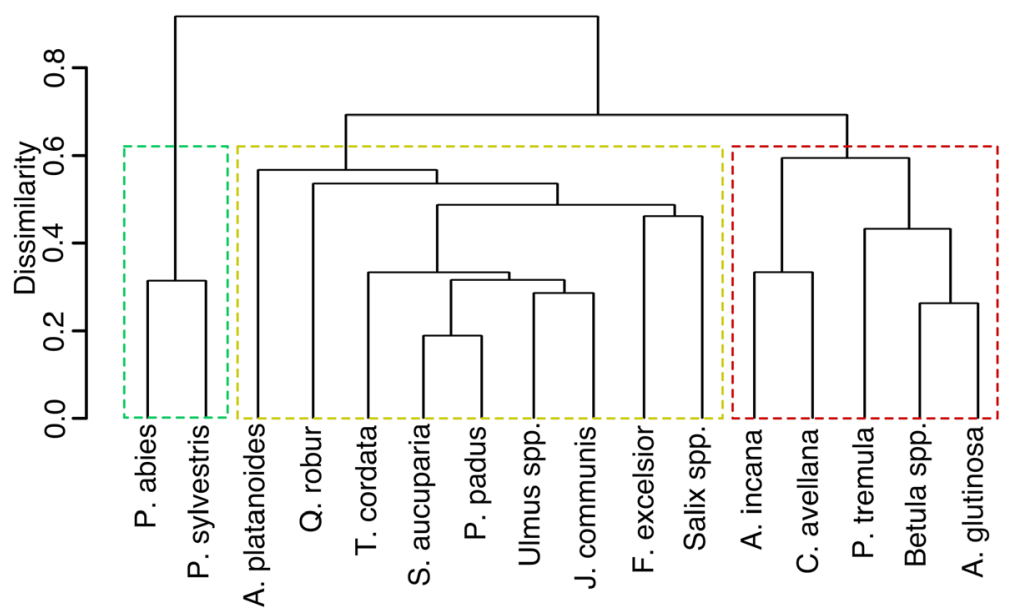

Fig. 5 Similarity of polypore species composition on Estonian native tree species according to cluster analysis (average linkage method; BrayCurtis dissimilarity). The main clusters of conifers, common soft-wooded deciduous tree species, and remaining tree or shrub species are indicated by coloured rectangles

on fine woody debris and in late decay stages. Parasitic polypores are relatively diverse on Quercus and exotic (ornamental) deciduous trees, but the scarcity of records among wood decay stages in these trees mainly shows poor substrate documentation.

In addition to natural substrates, there are observations of polypores on building timber. From 2002 to 2008, Pilt et al. (2009) reported four species as regular in wooded buildings: Antrodia serialis, A. sinuosa, Fibroporia vaillantii, and Fomitopsis pinicola. Parmasto (2004) additionally mentions rare occurrences of Fibroporia gossypium and Trametes ochracea as well as "Ceriporia purpurea" (probably C. bresadolae) on building timber in Estonia.

\section{DISCUSSION}

Our review demonstrates how integrating multiple data sources and their taxonomic and ecological appraisal can provide new perspectives on fungal species pools and their long-term dynamics. The practical opportunities discussed below included: posing new taxonomic and ecological hypotheses; fixing a state in the fungal biota for biodiversity monitoring purposes and retrospectives; providing a basis for red-listing individual species that considers all available data. The conservation issues can be further elaborated for management, which has been addressed elsewhere (Lõhmus et al. 2018b). Assessing the main factors behind changes in species lists helped us to understand actual changes in the biota and to prioritize research. We conclude that the Estonian polypore biota comprises over 260 species, of which roughly two-thirds were known 15 years ago according to their current species concepts, while the remaining third is divided between newly collected species, species distinguished from formerly known taxa, molecularly documented but yet-undescribed lineages, and species probably present but remaining to be found. Adding environmental DNA-samples to our basidiome data could be a next step to clarify the situation (cf. Kalsoom Khan et al. 2020).

\section{Estonian polypore biota as a part of the north-European species pool}

The composition of the current Estonian polypore biota can be primarily explained through their woodland habitats and fungal biogeography. Both these patterns refer to post-glacial vegetation development, notably the climate- and land use-driven transformation of Estonian forests during the last millennium (e.g., Reitalu et al. 2013). It remains poorly known how fungal distributions have responded to this history, but some insight can be obtained based on comparisons of current regional biotas.

We documented 221 polypore species and $>20$ to be described in Estonia. Comparing ours with the checklists in the neighbouring countries reveals extensive overlap of polypore biota across North-Europe, but clear latitudinal and longitudinal variation in relative abundance of species. Both the Finnish and Norwegian list include 251 species (Niemelä 2016, Tom Hofton, pers. comm.); but at least in Finland fewer species with 1-2 records than in Estonia (calculated from Niemelä 2016). Nevertheless, all the country lists now appear rather complete and the total species pool in Norway, Sweden (excluding its nemoral southern part), Finland and Estonia might be around 300 currently accepted species.

The part of this North-European species pool not found in Estonia comprises: (1) ca. 20 species having northern or north-eastern distributions in boreal forests; (2) several species having southwestern distribution in 
the Baltic Sea region, with Fennoscandia records mostly in southern Sweden; and (3) many extremely rare species having poorly explained scattered occurrences in Fennoscandia. Assigning the six species now considered Regionally Extinct in Estonia to the same groups reveals a disproportionate loss of northern species, with only Inonotus dryadeus representing group (2). Latitudinal patterns are further reflected by several southern species found in Estonia, but not in south Finland less than $100 \mathrm{~km}$ north. Of such species, Abortiporus biennis, Coltricia confluens, Haploporus tuberculosus, and Perenniporia narymica are also present in south Sweden (cf. group 2 above), and only Oxyporus latemarginatus and Trametopsis cervina have no Fennoscandian records at all. Some of these species are thermophilous; e.g., Gloeophyllum trabeum is confined to warm wooden indoor facilities in Finland but has a viable sexually reproducing population in the Estonian nature.

Longitudinal patterns are less apparent and, perhaps, less frequent, but two situations can be distinguished in our data. First, at least Ceriporia tarda, Junghuhnia autumnale and J. fimbriatella have continuous eastern distributions that reach Estonia, but rarely (if at all) Scandinavia. Similar species found in eastern Finland, but not in Estonia, are Antrodia hyalina, A. tanakai, and Postia persicina (Niemelä 2016). Secondly, the DNAbarcoding methods have helped us to record in Estonia Polyporus submelanopus and $P$. ulleungus with so-far known distributions in the Far East (Xue \& Zhou 2013, Tibpromma et al. 2017). That these species have not been recorded in Europe before may reflect insufficient molecular sampling or, alternatively, natural or humanmediated long-distance dispersal. Natural cross-border immigration from Russia has been hypothesized to have caused recent population increase in Estonia in some eastern species with continuous distributions, such as Amylocystis lapponica (Runnel et al. 2020). In the case of Far-Eastern species there is a possibility of artificial dispersal with long-distance trade in the Soviet period of Estonia (1945-1991).

\section{Taxonomically unclear and exotic taxa}

Taxonomically difficult situations remain common in European polypores despite much research undertaken. We documented, based on DNA (ITS) barcoding lineages, at least 20 likely undescribed species in Estonia alone. Since ITS differences can be minor among species in some genera, such as Antrodia and Antrodiella (Miettinen et al. 2012, Spirin et al. 2015), this number may increase when multiple genetic markers are used. At genus level, taxonomic revisions of Coltricia, Physisporinus, and Sistotrema (comprising at least 13 undescribed species in Estonia) appear as the priorities to clarify regional polypore biota. For some very rare lineages our data were too scarce to enable any ecological insight, and we encourage field work and international collaboration to add ecologically described records.

Some taxonomically resolved cases remain problematic in field sampling and for red-listing threatened species. For example, the collective taxa Postia alni, P. caesia, and Skeletocutis nivea remain in parallel use, because field identification of their cryptic constituent species is not reliable despite identification keys provided. How to apply those collective species concepts should be decided depending on questions being asked. If the goal is to record all constituent species of the collective taxa, vouchers should be regularly collected for laboratory assessment; e.g., sampling specimens from different substrates (Runnel et al. 2014).

Another uncertain part of the biota comprises exotic species. There is a considerable literature on the spread of wood-inhabiting fungi to exotic host trees, notably in plantations and on ornamental trees. Much less is known on how exotic host trees or anthropogenic substrates have changed the abundance or distribution patterns of the fungi (Burgess et al. 2016). In Estonia, parks, cemeteries, and gardens constitute poorly sampled habitats, and there are six polypore species ( $3 \%$ of the species pool) confined to introduced woody species in such settings. Four species are not applicable (NA) for conservation assessment: Phellinus tuberculosus and Postia balsamea have been only recorded on fruit trees in gardens, Ganoderma carnosum on Abies sp. (an exotic tree), and Ceriporia bresadolae on building timber. Additionally, Phellinus hippophaeicola has been only found once on a Hippophae rhamnoides (naturalized but mostly in plantations), and Phylloporia ribis (a frequent species) only occasionally outside gardens. A well-supported ecological conclusion, however, is that no exotic polypore has so far attained significant functional role in Estonian natural forests.

\section{Checklist-based detection of changes in fungal biota}

Monitoring fungal diversity remains a challenge (e.g., Halme et al. 2012) and, compared with plants or animals, fungal conservation perspectives have much poorer, often indirect, background knowledge on population dynamics. Unclear background undermines using fungi as indicators, which would be reasonable for different purposes (Lonsdale et al. 2008, Junninen \& Komonen 2011, Heilmann-Clausen et al. 2015). A solution has been combining ecological studies on current fungal habitat relationships with habitat changes of the past (e.g., Kouki et al. 2001, Penttilä et al. 2006, Junninen \& Komonen 2011). However, this requires key factors to be well known and includes hidden assumptions of stable regional species pools and habitat relationships in 
time. It cannot substitute documenting of changes in fungal biota, for which unfortunately no comprehensive and feasible survey methods exist.

Updated and critically revised regional checklists that integrate multiple data sources might thus remain crucial for monitoring full fungal diversity and for redlisting threatened species (Arnolds 2001). Yet, for credible interpretation of records, checklists must incorporate quality assessment, based on intensity and distribution of sampling effort, methodological heterogeneity, and species identification methods used. A set of critical issues assessed for our study (Table 5), implies that: (i) historical changes in the Estonian polypore biota can be summarized only by individual species (total numbers of species recorded are unreliable), (ii) at the current sampling intensity, 'safe minimum' temporal resolution of detecting strong trends and extirpation is ca. 30 years (see below), (iii) detectability (conspicuousness; identification; ecological impact) is a key consideration for evaluating the species' trends.

Case studies illustrate these points. Regarding point (ii), a few iconic species can be perhaps monitored even at $<10$ year resolution in Estonia (Runnel et al. 2020). More typically, however, a viable population of Trametes suaveolens (last seen in 1984 in the country) was discovered in much-visited Tallinn city in 2018; it would have been premature to consider the species Regionally Extinct (Runnel et al. 2018). Other long record gaps of rare, but apparently viable, populations include Hapalopilus aurantiacus and $H$. ochraceolateritius (1962-2006) and Dichomitus squalens (1980-2004). Highlighting point (iii), casual collection probability has varied by two orders of magnitude among Estonian polypore species, being smallest in species that produce poorly identifiable annual basidiomes (Lõhmus 2009). Such species are most likely to be missed in the country, especially if naturally rare, recently described, and inhabiting ecosystems not yet targeted by efficient ecological sampling schemes (see Lõhmus et al. 2018a). We can list around a dozen likely additions based on the well-studied Finnish biota (Niemelä 2016), e.g., Anomoporia kamtchatica, Antrodia infirma and $A$. mappa.

Considering temporal changes in the numbers of records by species (Table 2) against the study limitations (Table 5) reveals two broad patterns of change in the Estonian polypore diversity during the last 100 years. First, there is no evidence of changed total numbers of species, but apparent in the species pool is ca. 3-5\% turnover

Table 5 A quality assessment scheme (quality criteria) proposed for regional checklists of macrofungi, exemplified by the current study

\begin{tabular}{|c|c|c|}
\hline Quality criterion & Assessment for the current checklist & Limitations derived \\
\hline Completeness & $\begin{array}{l}<10 \% \text { unrecorded valid species (estimated from Chao } \\
\text { index based on singleton/doubleton ratio [1]; also by } \\
\text { analyzing species recorded in neighbouring countries) }\end{array}$ & $\begin{array}{l}\text { Total no. of recorded species poorly } \\
\text { comparable }\end{array}$ \\
\hline Taxonomic stability & $\begin{array}{l}\text { Ca. } 5 \% \text { recorded species taxonomically unresolved; up } \\
\text { to } 10 \% \text { further additions as currently undescribed lineages }\end{array}$ & $\begin{array}{l}\text { Previous checklists cannot be used for } \\
\text { direct comparisons }\end{array}$ \\
\hline $\begin{array}{l}\text { Documentation quality of } \\
\text { source data }\end{array}$ & $\begin{array}{l}\text { All collections in public fungaria; } 3 \% \text { with publicly accessible } \\
\text { DNA bar-codes (incl. vouchers of most taxa). > 95\% } \\
\text { observations geo-tagged and in public databases; however, } \\
\text { samples from ecological studies largely identified based on } \\
\text { observations. }\end{array}$ & $\begin{array}{l}\text { All species can be re-assessed from } \\
\text { original material, but not all individuals } \\
\text { (especially of common taxa). }\end{array}$ \\
\hline Presentation quality & $\begin{array}{l}\text { References to remarkable specimens and datasets presented. } \\
\text { Difficult specimens analyzed for phylogenetic relationships. } \\
\text { Taxonomic and ecological data linked. }\end{array}$ & $\begin{array}{l}\text { Undescribed species can be followed in } \\
\text { the material. }\end{array}$ \\
\hline $\begin{array}{l}\text { Differences between subsequent } \\
\text { checklists }\end{array}$ & $\begin{array}{l}\text { Within } 15 \text { yrs., } 15 \% \text { increase in the no. of valid species, } \\
\text { mostly due to adding ecological sampling designs. }\end{array}$ & $\begin{array}{l}\text { Different bias in historical [2] and current } \\
\text { data (numbers of records cannot be simply } \\
\text { corrected for sampling intensity) }\end{array}$ \\
\hline Geographic coverage & $\begin{array}{l}\text { Western part of the country poorly studied using ecological } \\
\text { sampling designs. }\end{array}$ & $\begin{array}{l}\text { Frequencies underestimated: taxa with western } \\
\text { distributions. }\end{array}$ \\
\hline Ecological representativeness & $\begin{array}{l}\text { Important understudied habitats: naturally disturbed areas, } \\
\text { riverine woodlands, oak stands, and wooded grasslands with } \\
\text { ancient trees [3-4], also gardens and buildings }\end{array}$ & $\begin{array}{l}\text { Frequencies underestimated: taxa inhabiting } \\
\text { semi-open natural or cultural landscapes. }\end{array}$ \\
\hline Species detectability bias & $\begin{array}{l}\text { Apparent in casual collections [5]; reduced in the main } \\
\text { ecological sampling scheme used [6]. }\end{array}$ & $\begin{array}{l}\text { Difficult-to-detect species poorly represented } \\
\text { in ecosystems with casual collection data only. }\end{array}$ \\
\hline e-DNA data & $\begin{array}{l}\text { Not included. Extensive sequencing of soil fungi and some } \\
\text { studies of wood samples have not revealed new species, but } \\
\text { would probably reveal wider ecological niches of many } \\
\text { taxa }[3,7] \text {. }\end{array}$ & $\begin{array}{l}\text { Frequencies and ecological niches } \\
\text { underestimated, specifically in mycorrhizal } \\
\text { species. }\end{array}$ \\
\hline
\end{tabular}


(i.e., up to 10 losses and a comparable number of gains). The losses comprise six species officially listed as Regionally Extinct (see above) and probably a few others not encountered for decades (Aurantiporus priscus - since 1980, Xanthoporus syringae - since 1998) or unknown to have formed actual population in Estonia (Ganoderma carnosum - a record in 1975, Antrodiella parasitica - in 1995, Perenniporia tenuis - in 2004). All extirpated species were very rare by the twentieth century. Most reliable gains are among well-established conspicuous species with habitats or locations frequently visited. Such recent novelties include at least three southern species (Coltricia cinnamomea and Inonotus ulmicola first discovered in 2002, and Trametopsis cervina - 2015), three species with eastern distributions (Ceriporia tarda - 2004, Pycnoporellus alboluteus and Junghuhnia autumnale - 2010) and Postia auricoma (2013). Less conspicuous newcomer candidates include Skeletocutis jelicii (4 locations since 2015), Hyphodontia latitans (a single record in 1992, then 11 records since 2012) and Gelatoporia subvermispora (a single record in 1991, then 12 records since 2006). Trametes gibbosa (a southern species) may also have recently formed a true population (three locations since 2005) after a single, possibly occasional record in 1954 .

Secondly, while species turnover refers to expansions and contractions of biogeographic ranges (perhaps related to climate change; cf. Musters \& van Bodegom 2018), other strong trends of extant Estonian polypores suggest ecological mechanisms. Thus, no clear declines are apparent in species inhabiting common deciduous trees, including no support to Parmasto's (2004) notes of decline in Pycnoporus cinnabarinus and Trichaptum biforme. There are some obvious increases instead, such as possibly climate-supported trends in southern species Hyphodontia flavipora (see also Heilmann-Clausen \& Boddy 2008), H. radula and Dichomitus campestris - all formerly been considered very rare (Parmasto 2004). Increases in record numbers of less conspicuous species in similar habitats (e.g., Antrodiella romellii and Ceriporia reticulata) are rather caused by better sampling. Assuming that increased records of most inconspicuous annual polypores on strongly decayed wood follow survey effort as well, the 1-2 similar species with reductions in records may indicate actual population declines - Porpomyces mucidus and, perhaps, Anomoporia bombycina.

In conifer-inhabiting polypores, three ecological tendencies can be distinguished. Some managementsensitive species that inhabit fallen Picea abies trunks have increased, probably due to efforts to protect old forests. The case of Amylocystis lapponica is well documented (Runnel et al. 2020); other rare species with similar record patterns are Antrodia piceata and Antrodiella citrinella; and among more frequent species -
Fomitopsis rosea, Junghuhnia collabens, and Postia undosa. Contrasting patterns, probably revealing population declines, are apparent in Onnia leporina, Climacocystis borealis and Skeletocutis stellae. Our data also support the decline of Gloeophyllum abietinum already noted by Parmasto (2004). We hypothesize that these species may be suffering from reduction of certain wood qualities, perhaps slowly grown trees (note that O. leporina and C. borealis often inhabit Picea abies snags). Finally, we notice increases in two formerly uncommon Pinus-inhabiting species that are now widespread in various forests, including extensive drained forests on former wooded mires - Junghuhnia luteoalba and Skeletocutis papyracea.

\section{Broad-scale ecological patterns}

Ecological case studies have been crucial for quantifying local variation in populations and assemblages, e.g. revealing their impoverishment by intensive forest management and the loss of natural forest (e.g., Penttilä et al. 2006, Junninen \& Komonen 2011; for Estonia, see Lõhmus 2011, Runnel \& Lõhmus 2017). Our review places those findings in the context of species pools, showing eventual extirpation of some species, but also some partial recoveries in protected forests and parallel, possibly climate-driven, shifts in distribution ranges (see above). Simultaneously, the taxonomic revisions clarify confusing reports of some putative old-forest indicator species inhabiting wider forest environments in Estonia. We now know that these represent distinct taxa (such as Antrodia cretacea instead of $A$. crassa, and Postia romellii instead of P. sericeomollis; cf. Runnel et al. 2014 and Runnel \& Lõhmus 2017), multiple species/lineages (such as among "Hapalopilus salmonicolor", Sidera vulgaris coll., and Physisporinus vitreus coll.) or misidentification (Postia lateritia). Based on our review, ca. half of the species listed 20 years ago as old-forest ('hemerophobic') polypores in Estonia (Trass et al., 1999) should probably be replaced or removed from that list to keep its focus.

Our analyses of species pools indicated that, under natural conditions, polypore assemblages would mostly vary along soil conditions and dominant forest trees. This parallels with findings on soil fungi (Tedersoo et al. 2020) and implies that forestry practices that change those factors, such as draining and artificial regeneration, are likely to be highly influential to all fungi. Distinct polypore biota on calcareous soils (alvar forests) was not known before; this finding is significant because alvar forests have been heavily degraded due to historical logging and agricultural use, and they regenerate slowly after being disturbed (Laasimer 1965). Even protected alvar forests have sometimes been mismanaged by removing dead wood, which is also essential for rare bryophytes (Meier \& Paal 2009). 
A pattern that soil fertility can create more assemblage variation than soil moisture is not directly applicable because our analysis separated their indirect effects via tree species composition. Both effects together explain why our ordination result (Fig. 2) resembles a Cajanderian organization of forest types solely based on soil characteristics (Lõhmus 1984). At a closer look, the pattern that polypore assemblages in drained peatland forests are more similar to meso-eutrophic forests on mineral soils than to other peatland forests has not been supported for several other organism groups - draining instead appears to produce novel assemblages (Remm et al. 2013). We also acknowledge that our approach to tree species effects was simplified (three categories analysed), and future studies should better address tree-species mixtures that are typical of hemiboreal forests (see also Tedersoo et al. 2016).

The importance of soil conditions highlights a necessity to better survey soil-inhabiting polypores. Our basidiomebased datasets suggested their higher diversity in poorer site conditions that might indicate stricter resource limitation and ecological advantages for mycorrhizal life-style in poor ecosystems. In general, however, polypores are rare and unlikely at key functional positions in mycorrizal assemblages in Estonia (e.g., Tedersoo et al. 2006, 2020; Bahram et al. 2011); a possible exception is Coltricia perennis - a dominant colonizer of early-successional Pinus sites (Visser 1995, Kwaśna et al. 2019). Summarizing the work done on DNA-based soil sampling could also improve our understanding of the ecology and conservation status of several species.

Regarding substrates, we found that the species having parasitic or brown-rot decay life strategies tend to be restricted to fewer host-tree species. This is probably linked with trade-offs of these life strategies, of which better understood are the highly demanding growth conditions inside live trees that require specific stresstolerant traits in parasites (Schwarze et al. 2013). Brownrot fungi may have distinct physiological limitations, indicated also by their typical disability to degrade pure cellulose (Nilsson \& Ginns 1979) or possibly lower wood pH optima (Highley 1976). However, these differences are in need of revision since the dichotomy of whiteand brown-rot fungi has been challenged based on genetic data (Riley et al. 2014). Physiological limitations set by wood chemistry and structure and tree defence mechanisms probably explain also our finding that phylogenetically closer tree species tend to host more similar pools of polypore species. Some ecological confounding effects are possible (i.e., related tree species may also grow in similar sites) but not very likely, given our result of the similarity of polypore assemblages in the hydrologically contrasting dry boreal and bog sites (both dominated by Pinus sylvestris).
Comparison of species pools on different woody substrates reveals an unexpected issue with natural stand regeneration - a sustainability indicator in forestry (Forest Europe, 2015). In the Estonian clear-cutting based forestry, natural regeneration on fertile sites mostly comprises Betula, Alnus, and Populus species, which cluster together by polypore assemblages (Fig. 5). Planting Picea abies may diversify this situation if the stands are allowed to develop into mixed stands with coarse woody debris present (Lõhmus 2011), while the third cluster of broad-leaved trees would still be absent. Given also that Picea abies hosts the most diverse polypore assemblages overall (Table 4), of which large part inhabits old stands (Runnel \& Lõhmus 2017), there is clear conservation motivation to use silvicultural alternatives that better account for substrate diversity (see also Lõhmus et al. 2018b). We also noticed that Fraxinus and Ulmus, both currently suffering from dieback due to introduced pathogens in Europe (Brasier 1991, Pautasso et al. 2013), have only moderately distinct assemblages when the remaining native tree diversity is present (Fig. 5). Thus, these specific dieback episodes are not likely to have strong negative impact on polypore biota in Estonia.

\section{A perspective}

Our broad question was whether, in the case of fungi, critically appraised checklists might provide standard input to global biodiversity indicators, and whether polypores could constitute a fungal group to be included. Looking at the insights obtained in Estonia, we consider this a promising direction, which depends on standardizing checklist quality, attaining a representative sample of checklists from different parts of the world, and including ecological data. Among potential values of such a scheme would be inclusion of many rare species and utilizing historical information. The possibility for a retrospective might even be a criterion for including fungal groups (e.g., epiphytic lichens; Ellis et al. 2011). However, it is unlikely that current monitoring and retrospectives can use similar methods, which again points at checklists as a common platform. We thus encourage new regional syntheses on polypores and other long-studied fungal groups.

\section{CONCLUSION}

Our review demonstrates how integrating multiple data sources and their taxonomic and ecological appraisal can provide new perspectives on fungal species pools, rare and undescribed species, and their long-term dynamics. The test case, the Estonian polypore biota, comprises over 260 species, of which 221 are verified extant species, and the remaining are molecularly documented but yetundescribed lineages or species probably present but remaining to be found. During the last 100 years, the biota experienced ca. 3-5\% species turnover, including 
directional changes but no obvious trend in diversity. Attaining a representative sample of high-quality checklists for flagship fungal groups from could be an approach to elaborating global indicators of fungal diversity.

\section{Supplementary Information}

The online version contains supplementary material available at https://doi. org/10.1186/s43008-020-00050-y.

Additional file 1. Estonian forest types, their main characteristics, and treatment in the polypore habitat analyses.

Additional file 2. The 2-ha plots of systematic polypore surveys in Estonia, their woodland type classifications and references to publications that used the survey results.

Additional file 3. Collection details, UNITE or GenBank accession numbers for ITS and LSU sequences of Estonian specimens analyzed in this study.

Additional file 4. Specimen vouchers, geographic location, and UNITE or GenBank accession numbers for public reference sequences (ITS and LSU) used in phylogenetic trees.

Additional file 5. Taxonomic notes and phylogenetic trees of difficult species.

Additional file 6. Non-metric multidimentional scaling (NMDS) ordination diagrams of polypore assemblages: (A) in forests on fertile and poor (excl. calcareous) soils and thin calcareous soils; (B) in woodlands with Picea and Pinus (including their mixedwood) or dominated by deciduous trees

Additional file 7. Numbers of common and unique species for habitat combinations not shown on Euler diagrams (Fig. 3).

Additional file 8. Nutritional-mode categorization of wood-inhabing polypore species with $>10$ records in Estonia (input data for Fig. 4).

\section{Abbreviations}

DNA: Deoxyribonucleic acid; rDNA: Ribosomal ribonucleic acid; ITS: Internal transcribed spacer; LSU: Large subunit: MRPP: Multi-response permutation procedures; NMDS: Non-metric multidimensional scaling

\section{Acknowledgements}

We acknowledge the huge work led by late Prof. Erast Parmasto with establishing the polypore research tradition and collections in Estonia. Many professional and amateur mycologists have contributed data and collections during the last 15 years, notably Indrek Sell, Urmas Ojango and Vello Liiv. Irja Saar organized these data in PlutoF database, sequenced casual polypore collections, shared two private sequences and assisted with loans from TU. Kadri Pärtel provided specimens for loan from TAAM and assisted with our work with E. Parmasto's archives. Kristel Turja and Irma Zettur helped with data management. The DNA-lab at the Tartu University Mycology Department, notably Rasmus Puusepp and Heidi Tamm, helped with molecular samples. When preparing the manuscript, we received help from Kadri Pöldmaa, Viacheslav Spirin and Josef Vlasak (comments on difficult species): Tom Hofton (unpublished list of Norwegian polypores); and Vello Liiv, Anneli Palo and Urmas Ojango (photo images). David L. Hawksworth and an anonymous reviewer kindly commented on the first version of the manuscript.

\section{Adherence to national and international regulations} Not applicable.

\section{Authors' contributions}

KR and AL planned the study, collected and interpreted the data, and drafted the manuscript. KR identified the collected fungal specimens and analysed the data. OM provided additional data on the "Difficult species" section, participated in writing of this section and reviewed the whole manuscript draft. All authors read and approved the final manuscript.

\section{Funding}

The systematic ecological surveys in 2004-2017, which provided most new data for the manuscript, were financed by the Estonian Research Council (grants SF0180012s09, IUT-34, and ETF6457 to A.L.), the Estonian Environmental Board (grant LLTOM16048) and the Estonian Centre of Environmental Investments (project 11061) to K.R. The financing covered design of the studies, collection, species identification, data analysis, interpretation and writing of this manuscript.

\section{Availability of data and materials}

The datasets generated and/or analysed during the current study are available in the Plutof repository:

https://plutof.ut.ee/\#/doi/10.15156/BIO/786358 https://plutof.ut.ee/\#/doi/1 $0.15156 / \mathrm{BIO} / 786363$

https://plutof.ut.ee/\#/doi/10.15156/BIO/786357

Ethics approval and consent to participate

Not applicable.

\section{Consent for publication}

Not applicable.

\section{Competing interests}

The authors declare that they have no competing interests.

\section{Author details}

'Department of Zoology, Institute of Ecology and Earth Sciences, University of Tartu, Vanemuise 46, 51005 Tartu, Estonia. ${ }^{2}$ Botanical Unit (Mycology), Finnish Museum of Natural History, University of Helsinki, Unioninkatu 44 00170 Helsinki, Finland.

Received: 12 December 2019 Accepted: 29 November 2020

Published online: 18 January 2021

\section{References}

Abarenkov K, Tedersoo L, Nilsson RH, Vellak K, Saar I, Veldre V, Parmasto E, Prous M, Aan A, Ots M, Kurina O, Ostonen I, Jõgeva J, Halapuu S, Pöldmaa K, Toots M, Truu J, Larsson KH, Köljalg U (2010) PlutoF - a web based workbench for ecological and taxonomic research, with an online implementation for fungal ITS sequences. Evolutionary Bioinformatics 6:189-196

Ahti T, Hämet-Ahti L, Jalas J (1968) Vegetation zones and their sections in northwestern Europe. Annales Botanici Fennici 5:169-211

Arnolds E (2001) The future of fungi in Europe: threats, conservation and management. In: Moore D, Nauta MM, Evans SE, Rotheroe M (eds) Fungal conservation: issues and solutions. Cambridge University Press, Cambridge, pp 64-80

Bahram M, Põlme S, Köljalg U, Tedersoo L (2011) A single European aspen (Populus tremula) tree individual may potentially harbour dozens of Cenococcum geophilum ITS genotypes and hundreds of species of ectomycorrhizal fungi. FEMS Microbiology Ecology 75:313-320

Birkemoe T, Jacobsen RM, Sverdrup-Thygeson A, Biedermann PH (2018) Insectfungus interactions in dead wood systems. In: Ulyshen M (ed) Saproxylic insects, zoological monographs, vol 1. Springer, New York, pp 377-427

Bortolus A (2008) Error cascades in the biological sciences: the unwanted consequences of using bad taxonomy in ecology. Ambio 37:114-119

Brasier CM (1991) Ophiostoma novo-ulmi sp. nov., causative agent of current Dutch elm disease pandemics. Mycopathologia 115:151-161

Burgess TI, Crous CJ, Slippers B, Hantula J, Wingfield MJ (2016) Tree invasions and biosecurity: eco-evolutionary dynamics of hitchhiking fungi. AoB plants 8 : plw076

Butchart SH, Walpole M, Collen B et al (2010) Global biodiversity: indicators of recent declines. Science 328:1164-1168

Chao A (1987) Estimating the population size for capture-recapture data with unequal catchability. Biometrics 43:783-791

Cushman SA, McKelvey KS, Flather CH, McGarigal K (2008) Do forest community types provide a sufficient basis to evaluate biological diversity? Front Ecol Environ 6:13-17

Dai YC (2012) Polypore diversity in China with an annotated checklist of Chinese polypores. Mycoscience 53:49-80

Dawson SK, Boddy L, Halbwachs H, Bässler C, Andrew C, Crowther TW, HeilmannClausen J, Nordén J, Ovaskainen O, Jönsson M (2019) Handbook for the 
measurement of macrofungal functional traits: a start with basidiomycete wood fungi. Functional Ecology 33:372-387

Di Marino E, Scattolin L, Bodensteiner P, Agerer R (2008) Sistotrema is a genus with ectomycorrhizal species- confirmation of what sequence studies already suggested. Mycological Progress 7:169-176

Dietrich HA (1856) Blicke in die Cryptogamenwelt der Ostseeprovinzen. Archiv für die Naturkunde Liv-, Esth- und Kurlands 1:261-414

Dietrich HA (1859) Blicke in die Cryptogamenwelt der Ostseeprovinzen. Archiv für die Naturkunde Liv-, Esth- und Kurlands 2:487-538

Donk MA (1948) Notes on Malesian fungi 1. Bulletin of the Botanical Gardens Buitenzorg 17:473-482

Donk MA (1964) A conspectus of the families of Aphyllophorales. Persoonia 3: 199-324

Donk MA (1971) Progress in the study of the classification of the higher basidiomycetes. In: Petersen RH (ed) Evolution in the higher Basidiomycetes. University of Tennessee Press, Knoxville, pp 3-25

Durkin L, Jansson T, Sanchez M, Khomich M, Ryberg M, Kristiansson E, Nilsson RH (2020) When mycologists describe new species, not all relevant information is provided (clearly enough). MycoKeys, pp 72-109

Ellis CJ, Yahr R, Coppins BJ (2011) Archaeobotanical evidence for a massive loss of epiphyte species richness during industrialization in southern England. Proceedings of the Royal Society of London, Series B 278:3482-3489

Floudas D, Binder M, Riley R et al (2012) The Paleozoic origin of enzymatic lignin decomposition reconstructed from 31 fungal genomes. Science 336:17151719

Forest Europe (2015) State of Europe's forests 2015. Ministerial Conference on the Protection of Forests in Europe, Madrid

Frey TEA (1973) The Finnish school and forest site types. In: Whittaker RH (ed) Ordination and classification of communities, Handbook of vegetation science, vol 5. Dr Junk Publishers, The Hague, pp 403-433

Fries EM (1874) Hymenomycetes Europaei. Berling, Sweden

Garbelotto MM, Lee HK, Slaughter G, Popenuck T, Cobb FW, Bruns TD (1997) Heterokaryosis is not required for virulence of Heterobasidion annosum. Mycologia 89:92-102

Gardes M, Bruns TD (1993) ITS primers with enhanced specificity for basidiomycetes - application to the identification of mycorrhizae and rusts. Molecular Ecology 2:113-118

Halme P, Heilmann-Clausen J, Rämä T, Kosonen T, Kunttu P (2012) Monitoring fungal biodiversity - towards an integrated approach. Fungal Ecology 5:750758

Halme P, Holec J, Heilmann-Clausen J (2017) The history and future of fungi as biodiversity surrogates in forests. Fungal Ecology 27:193-201

Hanso S, Hanso M (1999) Spread of Heterobasidion annosum in forests of Estonia. Metsanduslikud uurimused 31:162-172

Heilmann-Clausen J, Barron ES, Boddy L, Dahlberg A, Griffith GW, Nordén J, Ovaskainen O, Perini C, Senn-Irlet B, Halme P (2015) A fungal perspective on conservation biology. Conservation Biology 29:61-68

Heilmann-Clausen J, Boddy L (2008) Distribution patterns of wood-decay basidiomycetes at the landscape to global scale. In: Boddy L, Frankland JC, Van West P (eds) Ecology of saprotrophic basidiomycetes. Academic Press, Cambridge, pp 263-275

Hibbett DS (2016) The invisible dimension of fungal diversity. Science 351:11501151

Hibbett DS, Bauer R, Binder M, Giachini AJ, Hosaka K, Justo A, Larsson E, Larsson KH, Lawrey JD, Miettinen O, Nagy LG, Nilsson RH, Weiss M, Thorn RG (2014) Agaricomycetes. In: McLaughlin DJ, Spatafora JW (eds) The Mycota, systematics and evolution, vol 7A. Springer, New York, pp 373-429

Highley TL (1976) Hemicellulases of white-and brown-rot fungi in relation to host preferences. Material und Organismen 11:32-46

Holmer L, Renvall P, Stenlid J (1997) Selective replacement between species of wood-rotting basidiomycetes, a laboratory study. Mycological Research 101: 714-720

Honkaniemi J, Lehtonen M, Väisänen H, Peltola H (2017) Effects of wood decay by Heterobasidion annosum on the vulnerability of Norway spruce stands to wind damage: a mechanistic modelling approach. Canadian Journal of Forest Research 47:777-787

Hunter ML Jr (2005) A mesofilter conservation strategy to complement fine and coarse filters. Conservation Biology 19:1025-1029

IPBES (2018) The IPBES regional assessment report on biodiversity and ecosystem services for Europe and Central Asia. Secretariat of the Intergovernmental Science-Policy Platform on Biodiversity and Ecosystem Services, Bonn
Jõgi J, Tarand A (1995) Contemporary climate. In: Raukas A (ed) Estonia. Nature. Valgus, Tallinn, pp 183-216

Jülich W (1981) Higher taxa of basidiomycetes. Bibliotheca Mycologica 85:1-485

Junninen K, Komonen A (2011) Conservation ecology of boreal polypores: a review. Biological Conservation 144:11-20

Jüriado I, Paal J, Liira J (2003) Epiphytic and epixylic lichen species diversity in Estonian natural forests. Biodiversity and Conservation 12:1587-1607

Kalsoom Khan F, Kluting K, Tångrot J, Urbina H, Ammunet T, Sahraei SE, Rydén M, Ryberg M, Rosling A (2020) Naming the untouchable-environmental sequences and niche partitioning as taxonomical evidence in fungi. IMA Fungus 11:23

Karu A (1953) Dependence of root-rot (Fomes annosus) damage on soil conditions in spruce stands in Estonian S.S.R. In: Haberman H (ed) Loodusuurijate Seltsi juubelikoguteos. Eesti Riiklik Kirjastus, Tallinn, pp 196228 (in Estonian)

Katoh K, Rozewicki J, Yamada KD (2017) MAFFT online service: multiple sequence alignment, interactive sequence choice and visualization. Briefings in Bioinformatics. https://doi.org/10.1093/bib/bbx108

Kikas T, Bunce RG, Kull A, Sepp K (2018) New high nature value map of Estonian agricultural land: application of an expert system to integrate biodiversity, landscape and land use management indicators. Ecological Indicators 94:8798

Kõljalg U, Nilsson RH, Abarenkov K et al (2013) Towards a unified paradigm for sequence-based identification of fungi. Molecular Ecology 22:5271-5277

Korhonen A, Seelan JSS, Miettinen O (2018) Cryptic species diversity in polypores: the Skeletocutis nivea species complex. MycoKeys 36:45-82

Kouki J, Löfman S, Martikainen P, Rouvinen S, Uotila A (2001) Forest fragmentation in Fennoscandia: linking habitat requirements of woodassociated threatened species to landscape and habitat changes. Scandinavian Journal of Forest Research 16(S3):27-37

Kwaśna H, Behnke-Borowczyk J, Gornowicz R, Łakomy P (2019) Effects of preparation of clear-cut forest sites on the soil mycobiota with consequences for scots pine growth and health. Forest Pathology 49:e12494

Laasimer L 1965. Vegetation of the Estonian S.S.R. Valgus, Tallinn (in Estonian)

Lahti T, Väisänen RA (1987) Ecological gradients of boreal forests in South Finland: an ordination test of Cajander's forest site type theory. Vegetatio 68: $145-156$

Larsson A (2014) AliView: a fast and lightweight alignment viewer and editor for large datasets. Bioinformatics 30:3276-3278

Larsson J (2018) Eulerr: area-proportional Euler and Venn diagrams with ellipses. R package version 4.1.0. https://cran.r-project.org/package=eulerr

Lepik E (1931) Metsakahjulikud puumädanikud [Forest damaging wood decayers. ]. Eesti metsanduse aastaraamat 5:110-132 (in Estonian)

Lepik E (1940) Kastre-Peravalla looduskaitse reservaadi seenestik [Fungal biota of the Kastre-Peravalla nature reserve]. Looduskaitse 2:56-91 (in Estonian)

Lõhmus A (2009) Factors of species-specific detectability in conservation assessments of poorly studied taxa: the case of polypore fungi. Biological Conservation 142:2792-2796

Lõhmus A (2011) Silviculture as a disturbance regime: the effects of clear-cutting, planting and thinning on polypore communities in mixed forests. Journal of Forest Research 16:194-202

Lõhmus A, Kohv K, Palo A, Viilma K (2004) Loss of old-growth, and the minimum need for strictly protected forests in Estonia. Ecological Bulletins 51:401-411

Lõhmus A, Lõhmus P, Runnel K (2018a) A simple survey protocol for assessing terrestrial biodiversity in a broad range of ecosystems. PLoS One 13: e0208535

Lõhmus A, Nellis R, Pullerits M, Leivits M (2016) The potential for long-term sustainability in seminatural forestry: a broad perspective based on woodpecker populations. Environmental Management 57:558-571

Lõhmus A, Vunk E, Runnel K (2018b) Conservation management for forest fungi in Estonia: the case of polypores. Folia Cryptogamica Estonica 55: $79-89$

Lõhmus E (1984) Eesti metsakasvukohatüübid [Estonian Forest Site Types]. Eesti NSV Agrotööstuskoondise Info- ja juurutusvalitsus, Tallinn (in Estonian)

Lõhmus K, Liira J (2013) Old rural parks support higher biodiversity than forest remnants. Basic and Applied Ecology 14:165-173

Lonsdale D, Pautasso M, Holdenrieder O (2008) Wood-decaying fungi in the forest: conservation needs and management options. European Journal of Forest Research 127:1-22

Mace GM (2004) The role of taxonomy in species conservation. Philosophical Transactions of the Royal Society of London, Series B 359:711-719 
Meier E, Paal J (2009) Cryptogams in Estonian alvar forests: species composition and their substrata in stands of different age and management intensity. Annales Botanici Fennici 46:1-21

Meikar T, Uri V (2000) On the management of brushland in Estonia. Akadeemilise Metsaseltsi Toimetised 11:103-120

Miettinen O, Larsson E, Sjökvist E, Larsson KH (2012) Comprehensive taxon sampling reveals unaccounted diversity and morphological plasticity in a group of dimitic polypores (Polyporales, Basidiomycota). Cladistics 28:251-270

Musters CJM, van Bodegom PM (2018) Analysis of species attributes to determine dominant environmental drivers, illustrated by species decline in the Netherlands since the 1950s. Biological Conservation 219:68-77

Nguyen LT, Schmidt HA, von Haeseler A, Minh BQ (2015) IQ-TREE: a fast and effective stochastic algorithm for estimating maximum-likelihood phylogenies. Molecular Biology and Evolution 32:268-274

Niemelä T (2016) Suomen käävät [the polypores of Finland]. Norrlinia 31:1-430

Nilsson RH, Larsson KH, Larsson E, Kõljalg U (2006) Fruiting body-guided molecular identification of root-tip mantle mycelia provides strong indications of ectomycorrhizal associations in two species of Sistotrema (Basidiomycota). Mycological Research 110:1426-1432

Nilsson RH, Larsson KH, Taylor AFS, Bengtsson-Palme J, Jeppesen TS, Schigel D, Kennedy P, Picard K, Glöckner FO, Tedersoo L, Saar I, Kõljalg U, Abarenkov K (2018) The UNITE database for molecular identification of fungi: handling dark taxa and parallel taxonomic classifications. Nucleic Acids Research 47:D259D264

Nilsson T, Ginns J (1979) Cellulolytic activity and the taxonomic position of selected brown-rot fungi. Mycologia 71:170-177

Oksanen J, Blanchet FG, Friendly M, Kindt R, Legendre P, McGlinn D, Minchin PR, O'Hara RB, Simpson GL, Solymos P, Stevens MH, Szoecs E, Wagner H (2016) Vegan: community ecology package. $\mathrm{R}$ package version 2:4-1 https://CRAN. R-project.org/package=vegan

Ovaskainen O, Hottola J, Siitonen J (2010) Modeling species co-occurrence by multivariate logistic regression generates new hypotheses on fungal interactions. Ecology 91:2514-2521

Ovaskainen O, Schigel D, Ali-Kovero H, Auvinen P, Paulin L, Nordén B, Nordén J (2013) Combining high-throughput sequencing with fruit body surveys reveals contrasting life-history strategies in fungi. The ISME Journal 7:1696-1709

Parmasto E (2001) Fungi as indicators of primeval and old-growth forests deserving protection. In: Moore D, Nauta MM, Evans SE, Rotheroe M (eds) Fungal conservation: issues and solutions. Cambridge University Press, Cambridge, pp 81-88

Parmasto E (2004) Distribution maps of Estonian fungi, III. Pore fungi. Institute of Zoology and Botany of the Estonian Agricultural University, Tartu

Parmasto E (2012) Bibliography of biological (mainly mycological) publications by Erast Parmasto. Folia Cryptogamica Estonica 49:1-18

Parmasto E, Parmasto I (1997) Lignicolous Aphyllophorales of old and primeval forests in Estonia, 1. The forests of northern Central Estonia with a preliminary list of indicator species. Folia Cryptogamica Estonica 31:38-45

Pau M (2018) European white elms in manor parks of Tartu county: status and requirements, Thesis. Luua Forestry School, Estonia (in Estonian)

Pautasso M, Aas G, Queloz V, Holdenrieder O (2013) European ash (Fraxinus excelsior) dieback - a conservation biology challenge. Biological Conservation 158:37-49

Peay KG (2014) Back to the future: natural history and the way forward in modern fungal ecology. Fungal Ecology 12:4-9

Penttilä R, Lindgren M, Miettinen O, Rita H, Hanski I (2006) Consequences of forest fragmentation for polyporous fungi at two spatial scales. Oikos 114 $225-240$

Pilt K, Oja J, Pau K (2009) The wood-destroying fungi in buildings in Estonia. WIT Transactions on The Built Environment 109:243-251

Ramiadantsoa T, Hanski I, Ovaskainen O (2018) Responses of generalist and specialist species to fragmented landscapes. Theoretical Population Biology 124:31-40

Raudsaar M, Siimon KL, Valgepea M (2018) Yearbook Forest 2017. Estonian Environmental Agency, Tallinn

Raukas A, Kalm V, Karukäpp R, Lasberg K (2004) Pleistocene glaciations in Estonia. In: Developments in quaternary sciences, Vol. 2. Elsevier, Amsterdam, pp 8391

Reitalu T, Seppä H, Sugita S, Kangur M, Koff T, Avel E, Kihno K, Vassiljev J, Renssen H, Hammarlund D, Heikkilä M, Saarse L, Poska A, Veski S (2013) Long-term drivers of forest composition in a boreonemoral region: the relative importance of climate and human impact. Journal of Biogeography 40:15241534

Remm J, Lõhmus A (2011) Tree cavities in forests-the broad distribution pattern of a keystone structure for biodiversity. Forest Ecology and Management 262: 579-585

Remm L, Lõhmus P, Leis M, Lõhmus A (2013) Long-term impacts of forest ditching on non-aquatic biodiversity: conservation perspectives for a novel ecosystem. PLoS One 8:e63086

Renvall P (1995) Community structure and dynamics of wood-rotting fungi on decomposing conifer trunks in northern Finland. Karstenia 35:1-51

Riley R, Salamov AA, Brown DW, Nagy LG, Floudas D, Held BW, Levasseur A, Lombard V, Morin E, Otillar R, Lindquist EA, Sun H, LaButti KM, Schmutz J, Jabbour D, Luo H, Baker SE, Pisabarro AG, Walton JD, Blanchette RA, Henrissat B, Martin F, Cullen D, Hibbett DS, Grigoriev I (2014) Extensive sampling of basidiomycete genomes demonstrates inadequacy of the whiterot/brown-rot paradigm for wood decay fungi. Proceedings of the National Academy of Sciences 111:9923-9928

Runnel K, Järve S, Lõhmus A (2018) A lesson in urban mycology: critically endangered polypore Trametes suaveolens (Basidiomycota) re-discovered in Estonia. Folia Cryptogamica Estonica 55:91-95

Runnel K, Lõhmus A (2017) Deadwood-rich managed forests provide insights into the old-forest association of wood-inhabiting fungi. Fungal Ecology 27: 155-167

Runnel K, Põldmaa K, Lõhmus A (2014) 'Old-forest fungi'are not always what they seem: the case of Antrodia crassa. Fungal Ecology 9:27-33

Runnel K, Rosenvald R, Lõhmus A (2013) The dying legacy of green-tree retention: different habitat values for polypores and wood-inhabiting lichens. Biological Conservation 159:187-196

Runnel K, Sell I, Lõhmus A (2020) Recovery of a critically endangered polypore, Amylocystis lapponica, in the Estonian network of strictly protected forests. Oryx 54:478-482

Runnel K, Spirin V, Miettinen O, Vlasák J, Dai YC, Ryvarden L, Larsson KH (2019) Morphological plasticity in brown-rot fungi: Antrodia is redefined to encompass both poroid and corticioid species. Mycologia 111:871-883

Runnel K, Tamm H, Lõhmus A (2015) Surveying wood-inhabiting fungi: Most molecularly detected polypore species form fruit-bodies within short distances. Fungal Ecology 18:93-99

Ryberg M, Nilsson RH (2018) New light on names and naming of dark taxa. MycoKeys 30:31

Ryvarden L, Melo I (2017) Poroid fungi of Europe, 2nd ed. synopsis Fungorum 37

Sammul M, Kattai K, Lanno K, Meltsov V, Otsus M, Nõuakas L, Kukk D, Mesipuu M, Kana S, Kukk T (2008) Wooded meadows of Estonia: conservation efforts for a traditional habitat. Agricultural and Food Science 17:413-429

Sander H, Elliku J, Läänelaid A, Reisner V, Reisner Ü, Rohtla M, Šestakov M (2003) Urban trees of Tallinn, Estonia. Proceedings of the Estonian Academy of Sciences, Biology/Ecology 52:437-452

Schwarze FW, Engels J, Mattheck C (2013) Fungal strategies of wood decay in trees. Springer, Berlin

Sell I, Kotiranta H (2011) Diversity and distribution of aphyllophoroid fungi growing on common Juniper (Juniperus communis L.) in Estonia. Folia Cryptogamica Estonica 48:73-84

Senn-Irlet B, Heilmann-Clausen J, Genney D, Dahlberg A (2007) Guidance for conservation of macrofungi in Europe. www.wsl.ch/eccf/Guidance_Fungi.pdf

Singer R (1944) Notes on taxonomy and nomenclature of the polypores. Mycologia 36:65-69

Spirin V, Runnel K, Vlasák J, Miettinen O, Põldmaa K (2015) Species diversity in the Antrodia crassa group (Polyporales, Basidiomycota). Fungal Biology 119:12911310

Tamm H, Põldmaa K (2013) Diversity, host associations and phylogeography of temperate aurofusarin-producing Hypomyces/Cladobotryum including causal agents of cobweb disease of cultivated mushrooms. Fungal Biology 117:348367

Tamm Ü (2000) Aspen in Estonia. Eesti Loodusfoto, Tartu

Tedersoo L, Anslan S, Bahram M et al (2020) Regional-scale in-depth analysis of soil fungal diversity reveals strong $\mathrm{pH}$ and plant species effects in northern Europe. Frontiers in Microbiology 11:1953

Tedersoo L, Bahram M, Cajthaml T, Põlme S, Hiiesalu I, Anslan S, Harend H, Buegger F, Pritsch K, Koricheva J, Abarenkov K (2016) Tree diversity and species identity effects on soil fungi, protists and animals are context dependent. The ISME Journal 10:346-362 
Tedersoo L, Jairus T, Horton BM, Abarenkov K, Suvi T, Saar I, Köljalg U (2008) Strong host preference of ectomycorrhizal fungi in a Tasmanian wet sclerophyll forest as revealed by DNA barcoding and taxon-specific primers. New Phytologist 180:479-490

Tedersoo L, Suvi T, Larsson E, Köljalg U (2006) Diversity and community structure of ectomycorrhizal fungi in a wooded meadow. Mycological Research 110: 734-748

Thomson SA, Pyle RL, Ahyong ST et al (2018) Taxonomy based on science is necessary for global conservation. PLoS Biology 16:e2005075

Tibpromma S, Hyde KD, Jeewon R et al (2017) Fungal diversity notes 491-602: taxonomic and phylogenetic contributions to fungal taxa. Fungal Diversity 83:1-261

Trass H, Vellak K, Ingerpuu N (1999) Floristical and ecological properties for identifying of primeval forests in Estonia. Annales Botanici Fennici 36:67-80

Vilgalys R, Hester M (1990) Rapid genetic identification and mapping of enzymatically amplified ribosomal DNA from several Cryptococcus species. Journal of Bacteriology 172:4238-4246

Vink CJ, Paquin P, Cruickshank RH (2012) Taxonomy and irreproducible biological science. BioScience 62:451-452

Visser S (1995) Ectomycorrhizal fungal succession in Jack pine stands following wildfire. New Phytologist 129:389-401

White TJ, Bruns TD, Lee S, Taylor J (1990) Amplification and direct sequencing of fungal ribosomal RNA genes for phylogenetics. In: Innis MA, Gelfand $H$, Sninsky JS, White TJ (eds) PCR protocols: a guide to methods and applications. Academic Press, Cambridge, pp 315-322

Xue HJ, Zhou LW (2013) Polyporus submelanopus sp. nov. (Polyporales, Basidiomycota) from Northwest China. Mycotaxon 122:433-441

Zhou LW, Nakasone KK, Burdsall HH, Ginns J, Vlasák J, Miettinen O, Spirin V, Niemelä T, Yuan HS, He SH, Cui BK, Xing JH, Dai YC (2016) Polypore diversity in North America with an annotated checklist. Mycological Progress 15:771790

\section{Publisher's Note}

Springer Nature remains neutral with regard to jurisdictional claims in published maps and institutional affiliations.

Ready to submit your research? Choose BMC and benefit from:

- fast, convenient online submission

- thorough peer review by experienced researchers in your field

- rapid publication on acceptance

- support for research data, including large and complex data types

- gold Open Access which fosters wider collaboration and increased citations

- maximum visibility for your research: over $100 \mathrm{M}$ website views per year

At $\mathrm{BMC}$, research is always in progress.

Learn more biomedcentral.com/submissions 